University of Michigan Law School University of Michigan Law School Scholarship Repository

Articles

Faculty Scholarship

1986

\title{
Government Responsibility for Constitutional Torts
}

Christina B. Whitman

University of Michigan Law School, cwhitman@umich.edu

Available at: https://repository.law.umich.edu/articles/328

Follow this and additional works at: https://repository.law.umich.edu/articles

Part of the Common Law Commons, Constitutional Law Commons, Supreme Court of the United States Commons, and the Torts Commons

\section{Recommended Citation}

Whitman, Christina B. "Government Responsibility for Constitutional Torts." Mich. L. Rev. 85 (1986): 225-76.

This Article is brought to you for free and open access by the Faculty Scholarship at University of Michigan Law School Scholarship Repository. It has been accepted for inclusion in Articles by an authorized administrator of University of Michigan Law School Scholarship Repository. For more information, please contact mlaw.repository@umich.edu. 


\title{
GOVERNMENT RESPONSIBILITY FOR CONSTITUTIONAL TORTS
}

\author{
Christina B. Whitman*
}

This essay is about the language used to decide when governments should be held responsible for constitutional torts. ${ }^{1}$ Debate about what is required of government officials, and what is required of government itself, is scarcely new. What is new, at least to American jurisprudence, is litigation against government units (rather than government officials) for constitutional injuries. ${ }^{2}$ The extension of liability to institutional defendants introduces special problems for the language of responsibility. In a suit against an individual official it is easy to describe the wrong as the consequence of individual behavior that is inconsistent with community norms; the language of common-law tort, which refers explicitly to those norms, has seemed to provide a useful starting point for evaluating that behavior. ${ }^{3}$ When the defendant is an institution, the language of tort provides no such ground because tra-

* Professor of Law, University of Michigan. B.A. 1968, M.A. 1970, J.D. 1974, University of Michigan. - Ed.

1. The cases that $I$ will be discussing are, for the most part, brought against local governments under 42 U.S.C. $\S 1983$ :

Every person who, under color of any statute, ordinance, regulation, custom, or usage, of any State or Territory or the District of Columbia, subjects, or causes to be subjected, any citizen of the United States or other person within the jurisdiction thereof to the deprivation of any rights, privileges, or immunities secured by the Constitution and laws, shall be liable to the party injured in an action at law, suit in equity, or other proper proceeding for redress.

Similar questions arise in suits against state officials in their official capacity under section 1983 or Ex Parte Young, 209 U.S. 123 (1908).

2. Absent consent to suit, the federal and state governments have been immune from suits based on wrongs other than the taking of property for public purposes. Although federal officials may be sued for constitutional torts since the decision in Bivens v. Six Unknown Named Agents of Fed. Bureau of Narcotics, 403 U.S. 388 (1971), the federal government itself is liable only under the Federal Tort Claims Act, 28 U.S.C. $\$ \S 1346(\mathrm{~b}), 2671-80$, which refers to the law of the state in which the tort occurred rather than to federal constitutional law. 28 U.S.C. \& 1346(b). The eleventh amendment to the United States Constitution protects state governments from suits in federal courts for damages or other retrospective relief. See Edelman v. Jordan, 415 U.S. 651 (1974); see also Pennhurst State School \& Hosp. v. Halderman, 465 U.S. 89 (1984). And the Supreme Court has held that section 1983 was not intended by Congress to waive this immunity. Quern v. Jordan, 440 U.S. 332 (1979). Cities and counties could not be made defendants in section 1983 actions until Monell v. Department of Social Servs., 436 U.S. 658 (1978), overruled that portion of Monroe v. Pape, 365 U.S. 167 (1961), which held that municipalities are not "persons" within the meaning of the statute.

3. The most commonly cited indication of this tendency is Justice Douglas' statement, in the opening effort to define the scope of individual liability under section 1983: The statute "should be read against the background of tort liability that makes a man responsible for the natural consequences of his actions." Monroe v. Pape, 365 U.S. 167, 187 (1961). 
ditionally it has not been used to evaluate harms created by structures and contexts rather than by individuals. When discussions of institutional responsibility are couched only in terms borrowed from tort they are impoverished. The poverty of discussions cast in tort vocabulary can even be read to suggest that we simply have no norms for risk-creating behavior other than those applied to individuals.

I begin with a discussion of the language of responsibility as it has been developed in tort for tracing the consequences of individual behavior. Suits against institutions have been assimilated to this language through the doctrines of vicarious and strict liability. In constitutional tort litigation, however, these doctrines are not available, and the problem of institutional responsibility must be faced directly.

I then discuss a series of constitutional tort cases - those cases in which the Supreme Court has elaborated the conditions under which government liability will be imposed - in order to investigate this problem of language. In these cases the perspective adopted from tort encourages the Justices to convert the problem of institutional morality into one of individual morality; tort language leads them to look for individual choices and motives, for an actor or a "mind" that can be evaluated. In most of these cases the possibility of looking at an institution as a unit distinct from the separate individuals who compose it is not considered. For example, the Justices fail to see that injuries can be brought about quite inadvertently through the workings of institutional structures - through the massing or fragmentation of authority, or by the creation of a culture in which responses and a sense of responsibility are distorted.

Finally, I point to a few cases in which the Supreme Court has, perhaps inadvertently, considered the institution as a whole in determining whether constitutional norms have been violated and liability is appropriate. One of these, Owen v. City of Independence, ${ }^{4}$ like the cases discussed earlier, raises the issue of what is "official policy or custom." The others, Parratt v. Taylor 5 and Logan v. Zimmerman Brush Co., ${ }^{6}$ involve due process. We shall see that the promise of the due process cases has not been fulfilled. The pull of the individual tort model has proved too strong, leading the Court to retreat from the structural analysis employed in Parratt.

\footnotetext{
4. 445 U.S. 622 (1980).

5. 451 U.S. 527 (1981).

6. 455 U.S. 422 (1982).
} 


\section{The Language of Responsibility}

The distortion begins in tort. The paradigm common-law case, the framework in which issues of tort liability have been discussed, sets an individual victim against an individual defendant who has done some specific, relatively discrete act that affirmatively caused harm. The question in torts, as in the common law generally, has been: "When must we limit the presumptively free conduct of an individual?"' Legal standards are articulated as limitations on individuals. Liability is imposed when one individual goes too far and intrudes on the interests of another, presumably equally free, individual. Intrusive behavior is not flatly prohibited, as it is by criminal law. Assigning responsibility in tort is not, strictly speaking, dependent upon a conclusion that the defendant has gone too far by engaging in the harmful behavior; rather, it means that the defendant has gone too far if she fails to compensate those who have been injured by her conduct. The primary and most pressing questions in tort so defined do not address issues raised by more subtle or more diffusely caused harms, by affirmative obligations, or by claims that conduct should be prohibited and the resulting harm prevented.

It is certainly the case that not all tort litigants are individuals, but standards of behavior for groups and institutions have been derived without much modification from those devised for natural persons. There has been no separate language for harms caused by groups or institutions. The primary, and by now relatively comfortable, questions have been thought to be those raised by individual wrongs against other individuals. Individualism has been made into something more than an attractive ethical or political ideal. In litigation over harms, at least, it has been the method of analysis.

Tort law does not evaluate individuals as totally isolated units. To some extent, it has been sensitive to the contexts, organizational and otherwise, within which individuals act. Jurors are instructed that they are to evaluate the defendant's behavior by reference to what "the reasonably prudent person would do in the circumstances." 8 This formulation has proved enduring precisely because it allows the consideration of behavior in context; people who sit on juries may bring to bear their own sense of the cultural and situational constraints on individual action. ${ }^{9}$ It may thus be acceptable, for example, to argue that an

7. Cf. O.W. Holmes, The Common LaW 96 (1881).

8. 3 F. HARPER, F. JAMES \& O. GRAY, THE LAW OF TORTS $\S 16.2$, at 389 (2d ed. 1986) (emphasis added).

9. The instructions may require the jury to take into account certain constraints: For example, the jury may be told that an actor who is faced with an emergency is not to be held to the 
individual acted reasonably given the limited vision, information, or power created by his niche in a particular organization. Yet the focus of the inquiry is still on what is fair to expect of an individual in a given context, rather than on whether it is appropriate to require that the context be changed. The jury is asked to evaluate the particular, and relatively isolated, behavior of specified actors. The question, put that way, seems relatively straightforward. And many characteristics of tort litigation - the assumption that behavior can be fairly evaluated according to standards drawn from the jurors' own experiences; the rules about burden of proof, which fill in gaps in the narrative; and the abstract nature of the instructions to the jury ${ }^{10}$ - direct the attention of the court and the jury away from real difficulties in describing and understanding even individual behavior that causes discrete harm. Even less attention is paid to injuries that cannot be traced to particular behavior, but are attributable to institutions, or to communities or cultures within institutions - for the question is simply never put in that form.

In traditional tort law, the need to create standards uniquely addressed to organizational behavior has been avoided because questions of organizational responsibility have been assimilated into the doctrines of vicarious and strict liability. Under these doctrines, even when an institution is the defendant, the court focuses on the conduct of individual employees. Under vicarious liability, if the behavior of an employee is found wanting under the reasonably prudent person standard, the institution must pay. Institutional liability does not turn on a conclusion that the institution itself has been found to have caused harm; rather, the institution must pay because it employs a person who has caused harm. Doctrines of strict liability do hold institutions responsible without requiring evidence that an individual employee has done wrong. But here, too, liability is not based upon an analysis of the wrongfulness of the institution's conduct; it is justified, instead, as a mechanism for spreading the costs of injuries or for allocating costs to the enterprise in which the institution is engaged. Some forms of strict liability rest upon an inquiry into what the defendant has done in a way that seems to involve a moral evaluation of behavior; for example, strict products liability in torts requires a finding that

standard of conduct applied in more ordinary situations. See, e.g., Elmore v. Des Moines City Ry. Co., 207 Iowa 862, 224 N.W. 28 (1929); Pennington's Admr. v. Pure Milk Co., 279 Ky. 235, 130 S.W.2d 24 (1939). And the youthfulness of a plaintiff may be the subject of special instructions, see, e.g., Lewis v. Northern Ill. Gas Co., 97 Ill. App. 3d 227, 422 N.E.2d 889 (1981), or even entitle her to what is, in effect, an immunity. See, e.g., Dunn v. Teti, 280 Pa. Super. 399, 421 A.2d 782 (1980).

10. See text at note 8 supra. 
the defendant has marketed a defective product. ${ }^{11}$ But the reference point for evaluation is still an individual decisionmaker, though often a hypothetical one. In cases seeking to impose strict liability for defective product design, for example, one way to put the question is to ask whether the design decisions that were made would have been made by a reasonably prudent designer. ${ }^{12}$

These ways of avoiding direct evaluation of institutional conduct are not available in constitutional torts litigation. Vicarious liability of local governments for the torts of their employees has been emphatically rejected by the Supreme Court. ${ }^{13}$ Cost-allocation and costspreading rationales have been found to be inconsistent with the legislative history surrounding the enactment of section 1983,14 and both theories do seem out of place in constitutional litigation. Cost allocation is a way of encouraging appropriate reduction of accidents through the assignment of accident costs to those who can best decide whether the benefits flowing from an activity are worth the risks it runs. ${ }^{15}$ But cost allocation raises the possibility that an activity, if it is found to be too costly, will simply cease to take place. That is not an option for government, which cannot cease to exist. And, to treat constitutional wrongs as simply a cost of doing government business seems unpalatable. Both cost-allocation and cost-spreading rationales, if adopted, would suggest that constitutional injuries, like injuries redressed through more ordinary torts, may be incurred if the appropriate price is paid. Government without constitutional error, like a world without accidents, is impossible, but adopting a language for adjudication that focuses only on the decision of where to shift the costs of such error brings with it a measure of despair.

Since the devices that have deflected common-law tort doctrine from questions of institutional conduct have been eliminated in constitutional cases against government bodies, an opportunity has been created. The attention of the courts is necessarily directed toward the responsibility of the institution as distinct from that of the individual. It becomes possible to ask whether we have an adequate language for

11. See Restatement (SECOND) OF ToRTs § 402A (1965); see also Cronin v. J.B.E. Olson Corp., 8 Cal. 3d 121, 501 P.2d 1153, 104 Cal. Rptr. 433 (1972).

12. See, e.g., Wilson v. Piper Aircraft Corp., 282 Or. 61, 66, 577 P.2d 1322, 1325-26 (1978); Moran v. Faberge, Inc., 273 Md. 538, 552-54, 332 A.2d 11, 20-21 (1975).

13. Monell v. Department of Social Servs., 436 U.S. 658, 691 (1978).

14. Monell, 436 U.S. at 693-94. But see Owen v. City of Independence, 445 U.S. 622, 652-55 (1980), which accepts both rationales in rejecting a qualified immunity for municipal defendants. It is significant, I believe, that the question before the Court in Owen was not one calling for a determination of responsibility or "fault." See text at notes 163-78 infra. (1970).

15. G. Calabresi, The Costs of Accidents: A Legal and Economic ANalysis 68-94 
detecting and assessing injuries caused by organizations - for articulating what we expect from government as a system or structure, rather than what we expect from government officials as individuals.

What interests me is how difficult it has in fact been to talk about systemic or structural injuries, to ask (much less answer) these questions. Even though the Court has clearly posed the question as one of government responsibility independent of and distinct from vicarious responsibility for official acts, the Court's opinions, and the tests they articulate, still focus on the behavior of individual officials or postulate a hypothetical individual decisionmaker. I do not mean to suggest that the Court has been eager to hold individual officers liable. Quite the contrary. Individual officers are protected from personal liability by extensive immunities. ${ }^{16}$ These immunities are based on concerns that are unique to suits against individual defendants: Immunity doctrines reflect both the courts' lack of confidence in their own ability to evaluate and judge the behavior of persons in official positions who are subjected to conflicting, often extreme, pressures in their jobs, ${ }^{17}$ and a related sense that it may be both unfair and poor policy to burden individual human beings working under these conditions with the full weight of liability for often quite grievous harms. ${ }^{18}$ What we have, then, are many cases in which individuals as persons will not be held personally liable - the named defendants are the government as government and individual defendants sued only in their official capacity - but the discussion is still cast in terms of personal behavior and personal wrongdoing.

\section{Constitutional Litigation Against Institutions}

As doctrine in cases brought under section 1983 developed through the 1970s, judges in the lower federal courts, as well as in the Supreme Court, sought to distinguish constitutional torts from common-law torts. But they tended to see that question as: Should liability for constitutional torts go as far as liability under the common law? Should it, for instance, include liability for negligence? ${ }^{19}$ Or is only

16. E.g., Harlow v. Fitzgerald, 457 U.S. 800 (1982); Stump v. Sparkman, 435 U.S. 349 (1978); Pierson v. Ray, 386 U.S. 547 (1967).

17. Harlow v. Fitzgerald, 457 U.S. $800,815-19$ (1982); Wood v. Strickland, 420 U.S. 308, 319-21 (1975).

18. See Stump v. Sparkman, 435 U.S. 349, 363-64 (1978); Imbler v. Pachtman, 424 U.S. 409, 424-28 (1976).

19. See, e.g., Bonner v. Coughlin, 545 F.2d 565, 568 (7th Cir. 1976) ("[T] me majority of Circuits hold that mere negligence does not state a claim under Section 1983 [citing 13 circuit cases]. Otherwise the federal courts would be inundated with state tort cases . . .."), cert. denied, 435 U.S. 932 (1978). 
that behavior which is covered by the most "egregious" of commonlaw torts of sufficient importance to merit constitutional sanction? An approach with the opposite emphasis simply was not considered. ${ }^{20}$ The courts did not ask whether constitutional tort litigation might reach questions of liability that were not addressed by common-law tort, whether different measures of responsibility (measures not dependent upon inquiries into efficiency or motive or intent) might be more appropriate in evaluating government behavior.

This extremely cautious, even suspicious, approach to constitutional tort actions - coupled with an attempt to limit constitutional responsibility to egregious individual acts - can be found in a Supreme Court opinion written several years before the Court accepted an interpretation of section 1983 that would permit suits against governmental entities. The case is Rizzo v. Goode, ${ }^{21}$ a class action in which the plaintiffs sought structural injunctive relief to reduce police abuses in the city of Philadelphia. Because the law at that time did not permit direct suits against cities, the action was brought against "those in charge" 22 of the city police. The majority opinion is remarkable because the Court insisted on characterizing the case as a suit between individual plaintiffs and individual defendants, yet simultaneously demonstrated considerable reluctance, even anger, at the idea of holding the individual defendants responsible for the police misconduct under attack. This reluctance permeates the opinion even though the defendants were sued only in their official capacities and would have been subject at most to injunctive relief.

Justice Rehnquist, writing for the majority, began by adopting the common-law tort paradigm as the standard for the outer limit of federal judicial authority. That paradigm represented, for him, what is meant by article III's reference to "cases" and "controversies." A lawsuit, if it is to be comprehensible to, and fall within the authority of, a court, must be put into the framework of individual versus individual, and the dispute must be about specific and precisely defined injuries by individual defendants to individual plaintiffs. Article III, read this way, requires that the plaintiffs point to an "injury in fact" that they have suffered at the hands of the defendants. Forcing the case into this framework, Justice Rehnquist described the "individual

20. But see Monroe v. Pape, 365 U.S. 167, 196 n.5 (1961) (Harlan, J., concurring) ("It would indeed be the purest coincidence if the state remedies for violations of common-law rights by private citizens were fully appropriate to redress those injuries which only a state official can cause and against which the Constitution provides protection.").

21. 423 U.S. 362 (1976).

22. 423 U.S. at 380. 
[plaintiffs'] claim to 'real and immediate' injury" in Rizzo as plausibly based solely on the fear of "what one of a small, unnamed minority of policemen might do to them." ${ }^{23}$ Thus, despite the district court's conclusion that the plaintiffs had established a pattern of violations of constitutional rights on the part of the Philadelphia police, the plaintiffs' "real" controversy was found to be, not with "those in charge" of the police department, but with the individual officers on the street who had directly inflicted unconstitutional blows. The Court would not hear the claim, accepted by the lower court, that the police department had failed to provide sufficient disincentives to police misconduct, nor the claim that the department had by "official indifference" 24 actually encouraged such behavior. These claims could not be heard because there was no room in the Court's concept of a "case" for evaluation of police practices as a system. The individual conduct of individual defendants was assumed to be the only possible object of judicial scrutiny; relief would be inappropriate in the absence of evidence of a tight causal connection between harm to specific named plaintiffs and the conduct of specific named defendants. In fact, since this suit named only higher-level officials as defendants, a showing of quite deliberate wrongdoing on the part of those officials was required. The suit could not proceed because there had been no showing of an "affirmative link" between established incidents of police misconduct against the named plaintiffs and "the adoption of [a] plan or policy by [defendants] - express or otherwise - showing their authorization or approval of such misconduct."25

This formulation, which focuses on a "plan or policy," became quite important in post-Rizzo cases. It requires not only individual involvement by named officials, but individual involvement in the form of explicit policy formulation. The Rizzo plaintiffs' theory of causation was found to be too loose because they could point to no explicit decision on the part of the defendants as the source of their injury. This requirement, with its insistence on proof of explicit and decisive action, is far more strict than any that has been applied at the common law. The plaintiffs' argument in Rizzo was not a generalized and unspecific attack on "the system" of the sort that would not have been heard in tort. The plaintiffs claimed quite specific wrongdoing on the part of the individual defendants - that they had neglected to fulfill their constitutional duty to take steps to curb a pattern of police misconduct. Justice Blackmun, in dissent, characterized the alleged

23. 423 U.S. at 372 .

24. 423 U.S. at 382 (Blackmun, J., dissenting).

25. 423 U.S. at 371. 
wrongdoing as "consciously permitting . . . subordinates ... to violate the constitutional rights of persons with whom they deal."26 But, according to Justice Rehnquist, to say that officials have a "duty" to respond to a pattern of abuse by their subordinates, and to say that there has been a "default" when the pattern continues, "blurs accepted usages and meanings in the English language." 27 Since the plaintiffs had claimed only a tort of omission and thus made such a weak showing of individual responsibility, the dispute did not fit into Justice Rehnquist's concept of a "case." Rather, it was classified as political - "a 'controversy' between the entire citizenry of Philadelphia and [their] elected and appointed officials" 28 — and thus unfit for judicial resolution. ${ }^{29}$

The dissenters in Rizzo, joining in an opinion by Justice Blackmun, were willing to let the plaintiffs' action proceed, but they, too, saw the key question as one of individual behavior. They stressed the district court's finding of "official indifference" 30 and would have based liability on the named defendants" "acquiescence" in the face of "notice of the unconstitutional conduct of their subordinates." 31 The possibility of liability for mere "failure to supervise" was suggested, but left for another day. ${ }^{32}$ Justice Blackmun's disagreement with Justice Rehnquist was not over the propriety of turning an attack on the incentives and disincentives created by the practices of the Philadelphia Police Department into a case about individual misconduct. Justice Blackmun disagreed, instead, about what the standard for evaluating individual conduct should be.

In 1961, the Court had held in Monroe v. Pape 33 that cities could not be sued under section 1983. Between that time and 1978, the

26. 423 U.S. at 385.

27. 423 U.S. at 376.

28. 423 U.S. at 371.

29. Ironically, even those Justices most committed to this perspective have indicated in other contexts that the more a case looks like a common-law case the less likely it is to be a proper constitutional action. In Paul v. Davis, 424 U.S. 693 (1976), decided the same Term as Rizzo, it was the fit between the plaintiff's case and a common-law action for defamation that led Justice Rehnquist, again writing for the Court, to dismiss the federal suit. Despite the plaintiff's allegation that police action had deprived him of his interest in his reputation without due process of law, the Court did not see a constitutional cause of action. Instead, there was simply a "legally cognizable injury which may have been inflicted by a state official acting under "color of law." " 424 U.S. at 699. A more accommodating response, the Court feared, would "derive from congressional civil rights statutes a body of general federal tort law." 424 U.S. at 701 (citations omitted).

30. 423 U.S. at 382.

31. 423 U.S. at 385 n.2 (quoting Schnell v. City of Chicago, 407 F.2d 1084, 1086 (7th Cir. 1969)).

32. 423 U.S. at 385.

33. 365 U.S. 167 (1961). 
named defendants in constitutional tort cases like Rizzo were individuals (even though often sued in their official capacity). Language borrowed from ordinary tort actions was, therefore, not strikingly inappropriate. In 1978, the Court overruled Monroe. Monell v. Department of Social Services ${ }^{34}$ held for the first time that constitutional tort actions could be brought against municipal corporations. Monell, then, was the first case in which the Court struggled explicitly with the question: When is a wrong "done by" a government?35

But the way in which that question was to be addressed was inevitably influenced by the continuing debate over whether any section 1983 defendant could be held liable for "mere negligence" and by the discussion in Rizzo v. Goode. The doctrinal background of Monell itself also encouraged the Justices to talk of entity responsibility as parallel to individual liability rather than to develop a language more sensitive to the unique ways in which institutions cause harms. The question before the Court in Monell was one of statutory interpretation, and the word to be interpreted was "person": Was a municipal corporation a "person" subject to suit within the language of section 1983 ? $^{36}$ One way to respond, perhaps the most obvious, was to look to the meaning of "person" as used generally in statutes in 1871. The Court concluded that by that time "it was well understood that corporations should be treated as natural persons for virtually all purposes of constitutional and statutory analysis." 37 Municipal corporations were included as statutory referents by an extension of the concept of "person"; this quite naturally led the Court to stress the similarities between municipal corporations and natural persons, rather than the differences. Also, section 1983, and its predecessor, defined the defendant class as whoever "subjects [another], or causes [her] to be subjected" to a constitutional wrong. ${ }^{38}$ Both verbs, and most especially "cause," seemed to the Court to direct attention to ordinary tort con-

34. 436 U.S. 658 (1978).

35. That question was submerged in the official-capacity cases like Rizzo, where individuals were named as defendants but sued "in their official," as opposed to their "individual," "capacity." These were treated as suits against individuals rather than institutions, but individual assets were not at risk. One effect of Monell was to assimilate and redefine these cases. The Court suggested, 436 U.S. at 690 n.55, and has since stated explicitly, see Brandon v. Holt, 469 U.S. 464, 471-73 (1985), that these official-capacity suits are now, and always have been, in practical effect, suits against the municipal employers who will pay for any damages awarded. One consequence is that defenses available to municipal corporations, rather than the immunities available to individual defendants, apply in official-capacity litigation. 469 U.S. at 472-73.

36. The statute provides that "Every person who [deprives another of his or her federal rights] shall be liable ...." 42 U.S.C. $\$ 1983$ (1982) (emphasis added).

37. 436 U.S. at 687 (emphasis added).

38. 42 U.S.C. § 1983 (1982) (emphasis added). The original Act read "shall subject, or cause to be subjected." 17 Stat. 13 (1871). 
cepts of causation - in other words, to harms caused in the ways in which individuals ordinarily harm each other. Its analysis of the statute, then, led the Court further along the path it had already marked out in discussing supervisor liability in Rizzo v. Goode.

The bulk of the opinion in Monell was devoted to a justification of its overruling of the previous decision in Monroe. The problem with Monroe, the Court said, was that it had relied too heavily upon, and indeed misread, a legislative skirmish that took place simultaneously with the enactment of the predecessor of section 1983. That skirmish resulted in the rejection of the Sherman amendment, which, though the proposal took a variety of forms in the course of the legislative debate, essentially sought to impose liability on municipal corporations for injuries caused by assemblies of the sort organized by the $\mathrm{Ku}$ Klux Klan. ${ }^{39}$ In Monroe the Court had read that rejection as based upon Congress' belief that it lacked the power to impose any obligation upon a municipality; if that was what Congress believed, it could scarcely have intended to impose liability upon cities and counties under section 1983.

Monell recharacterized the rejection of the Sherman amendment in a way that cast no doubt on Congress' belief in its power to impose some sort of liability on municipal corporations. According to this recharacterization, it was not the imposition of just any civil liability upon municipalities that Congress thought beyond its powers in 1871; what was thought to be inappropriate, and indeed unauthorized by the Constitution, ${ }^{40}$ was imposing vicarious liability for the actions of rioters who were not necessarily employees or even citizens of the municipal defendant. The rejection of the Sherman amendment, then, cast no doubt upon Congress' decision to hold a municipality liable "for its

39. The first conference committee draft of the Sherman amendment, for example, created a cause of action for persons injured by

any persons riotously and tumultuously assembled together, with intent to deprive any person of any right conferred upon him by the Constitution and laws of the United States, or to deter him or punish him for exercising such right, or by reason of his race, color, or previous condition of servitude....

The action could be brought against the county, city, or parish in which the riot had occurred. See Cong. Globe, 42d Cong., 1st Sess. 749, 755 (1871), quoted in Monell, 436 U.S. at 666.

40. The fear was that the amendment would impose police obligations on municipalities even where no such obligation had been imposed by the state. This would violate a notion of "coordinate sovereignty," articulated in Supreme Court opinions such as Prigg v. Pennsylvania, 41 U.S. (16 Pet.) 539 (1842), and Collector v. Day, 78 U.S. (11 Wall.) 113 (1871), by raising the threat that federal obligations would disable municipal corporations from carrying out state policies. See Monell, 436 U.S. at 673-83. In Pembaur v. City of Cincinnati, 106 S. Ct. 1292 (1986), the Court characterized the discussion of legislative history in Monell as attributing the defeat of the Sherman amendment to the argument "that, in effect, [the amendment] imposed an obligation on local governments to keep the peace, and that the Federal Government could not constitutionally require local governments to keep the peace if state law did not." $106 \mathrm{~S}$. Ct. at 1298 n.7. 
own violations." The problem with the Sherman amendment was that it "imposed damages without regard to whether a local government was in any way at fault."41 To avoid that problem it becomes important to ask, in any suit against a local government, whether the municipal defendant is itself "at fault," whether the constitutional violation is truly "its own."

The rejection of the Sherman amendment meant, under Monell's revised reading of legislative history, that some basis for government liability other than vicarious liability for the acts of individuals must be found. This is the theme to which the Court in Monell kept returning. It is a difficult theme, for there is no obvious way to distinguish the acts of a municipality from the acts of the individuals whom it employs, yet the Court felt committed by the rejection of the Sherman amendment to the proposition "that a local government may not be sued under $\S 1983$ for an injury inflicted solely by its employees or agents." 42 The rejection of vicarious liability ${ }^{43}$ seemed to suggest to the Court that the defendant municipality must be tied to the constitutional injury alleged in a way that parallels the tie between the act of an individual defendant and a plaintiff's injury in tort. Any looser, or different, connection between defendant and injury would mean that the injury was not the defendant's "fault."

In comparison to the extended reinterpretation of legislative history that justified the Court's overruling of Monroe, virtually no attention was given in Monell to the definition of what were indeed the municipality's "own violations." The Court appeared to think the answer to that obvious after its rejection of vicarious liability. And on the facts of Monell, the answer could not have been more obvious. Plaintiffs were challenging what all parties conceded to have been "a citywide policy of forcing women to take maternity leave after the fifth month of pregnancy." 44 The case involved a constitutional attack on "formal, written policies of" city agencies, ${ }^{45}$ and the attribution of the constitutional violation to the municipality was quite straightforward.

41. 436 U.S. at 681 n. 40 .

42. 436 U.S. at 694.

43. The Court's conclusion that section 1983, read in light of the legislative history, prohibits any imposition of vicarious liability upon municipal corporations is ultimately unpersuasive. All that the rejection of the Sherman amendment indicated, by the Court's own description, was that cities were not to be held vicariously liable for the acts of those who were neither employees nor citizens. See City of Oklahoma City v. Tuttle, 471 U.S. 808, 839 (1985) (Stevens, J., dissenting) (citing Monell v. Department of Social Servs., 436 U.S. 658, 666-76 (1977)); Pembaur v. City of Cincinnati, 106 S. Ct. 1292, 1303 (1986) (Stevens, J., concurring in part and concurring in the judgment).

44. 436 U.S. at $661 \mathrm{n} .2$.

45. 436 U.S. at 705 (Powell, J., concurring). 
But the Court did not stop with saying that Monell was an easy case. With virtually no introduction, it announced its definition of a municipality's "own violations." The critical analysis is found in Part III of the Monell opinion. The Court began by stating that, since Congress had intended to allow suits against local governments to be brought under section 1983, such defendants could be sued "where, as here, the action that is alleged to be unconstitutional implements or executes a policy statement, ordinance, regulation or decision officially adopted and promulgated by that body's officers." 46 "Moreover," it added cryptically, "like every other $\S 1983$ 'person,' " a municipality may be sued for "deprivations visited pursuant to governmental 'custom' even though such a custom has not received formal approval through the body's official decisionmaking channels." 47 "Custom" was further defined only by citations to prior cases in which the term was said to encompass "persistent and widespread discriminatory practices of state officials [which,] [a]lthough not authorized by written law, [had become] so permanent and well settled as to constitute a 'custom or usage' with the force of law." 48 What was not permissible was holding a municipality "liable solely because it employs a tortfeasor - or, in other words, a municipality cannot be held liable under $\S 1983$ on a respondeat superior theory."49 To the Court, this seemed to exhaust the possible bases of municipal liability:

We conclude, therefore, that a local government may not be sued under $\S 1983$ for an injury inflicted solely by its employees or agents. Instead, it is when execution of a government's policy or custom, whether made by its lawmakers or by those whose edicts or acts may fairly be said to represent official policy, inflicts the injury that the government as an entity is responsible under $\S 1983 .{ }^{50}$

Although the Court warned that it was not addressing "what the full contours of municipal liability under $\S 1983$ might be," has been read as leaving open questions of immunity, rather than suggesting that "official policy and custom" is only a partial definition of the scope of municipality liability. ${ }^{52}$

There is no further explanation of why "official policy and custom" might be an exhaustive description of the ways in which a gov-

46. 436 U.S. at 690 .

47. 436 U.S. at $690-91$.

48. 436 U.S. at 691 (quoting Adickes v. S.H. Kress \& Co., 398 U.S. 144, 167-68 (1970)). The Court also referred to Justice Frankfurter's opinion in Nashville, C. \& St. L. Ry. Co. v. Browning, 310 U.S. 362, 369 (1940). Monell, 436 U.S. at 691 n.56.

49. 436 U.S. at 691.

50. 436 U.S. at 694.

51. 436 U.S. at 695 .

52. See Owen v. City of Independence, 445 U.S. 622, 624, 633 (1980). 
ernment can nonvicariously cause constitutional injuries. In Monell the Court seemed to be looking for something parallel to an individual's decision to act, some indication of will or intent. Those concepts cannot be applied in any obvious way to a government, though formal, written policies may come close enough to the expressions of individual will to make the analogy seem possible and attractive. But formal policies are not in any real sense analogous to individual decisions to act; they are more closely analogous to formal statements or descriptions by individuals of intent to act. The obvious problem with limiting liability to situations in which the actor expresses his or her or its intent to act is that liability can often be avoided by the simple expedient of keeping silent. That, presumably, is why the Court included liability based on "official custom" as well as "official policy." But the "custom," apparently, must be "so permanent and well settled as to [have] the force of law." 53 That is, it serves only as a stand-in for unexpressed intent.

The hard cases are those in which there is no written or otherwise explicit statement of intent, yet the plaintiff alleges that the municipality has caused an injury in a way that cannot be analyzed by analogy to a tort done by an individual actor. One case in which the Court gave some indication of how it might view such claims is City of Oklahoma City v. Tuttle. ${ }^{54}$ Tuttle was shot and killed by Rotramel, a city police officer who had been called to the scene of a "robbery in progress." 55 Tuttle's widow sued the officer and the city for depriving her husband of life without due process of law and for using excessive force. At trial she prevailed against the city but not against the officer. The verdict against the city was affirmed by the court of appeals ${ }^{56}$ but reversed by the Supreme Court. The seven Justices who reiterated the Monell requirement that official policy or custom must be established to proceed against the city ${ }^{57}$ all agreed on this result. The problem, the Justices concluded, was that under the instructions the jury could have found the city liable solely on the basis of proof of the incident in which Tuttle had died. The trial judge had instructed the jury that "a single, unusually excessive use of force may be sufficiently out of the

53. 436 U.S. at 691 (quoting Adickes v. S.H. Kress \& Co., 398 U.S. 144, 168 (1969)).

54. 471 U.S. 808 (1985).

55. The parties stipulated at trial that Tuttle had placed the call to the police. 471 U.S. at 811. There was testimony that the officer, upon arriving at the site, was told that no robbery had occurred. 471 U.S. at 811.

56. Tuttle v. City of Oklahoma City, 728 F.2d 456 (10th Cir. 1984).

57. Justice Stevens would have overruled that part of Monell that refused to allow a city to be held on the basis of vicarious liability. 471 U.S. at 841-42. Justice Powell took no part in the decision. 
ordinary to warrant an inference that it was attributable to inadequate training or supervision amounting to 'deliberate indifference' or 'gross negligence' on the part of the officials in charge."58

In concluding that this instruction was erroneous the Supreme Court rejected the possibility, accepted by both the district court and the Tenth Circuit Court of Appeals, that the character of a single incident could in itself indicate that official policy or custom was deficient. 59 To affirm a finding of liability on these grounds, the Justices feared, would be equivalent to holding the city vicariously liable, responsible simply because it had employed the offending officer. ${ }^{60}$ The holding in Tuttle is not unremarkable given Monell's rejection of vicarious liability. It may simply be read as saying that one incident without more tells us very little about institutional wrongdoing. The more interesting, and more troubling, aspects of the Tuttle opinions lie in the various remarks about what would be evidence of institutional error. On that point, the signals given by the Court were quite confusing.

At trial the jury had held the city liable to Mrs. Tuttle for $\$ 1,500,000$ in damages, but it found for the individual police officer on the ground that he had acted in good faith. This result can be read, and was read by the court of appeals, to indicate that the jury felt that

\section{471 U.S. at 813.}

59. The court of appeals, describing the incident, pointed out that

Tuttle did not at any time brandish a weapon. In fact, Tuttle made no overt threat. Nevertheless, Officer Rotramel drew his gun and shot the decedent in the back. The latter was a short distance from the officer and had gone down on one knee. No weapon was found on the decedent; there was allegedly a toy gun which was said to have been found in Tuttle's possession. This was not visible to the officer, but he said that he was apprehensive that the decedent had a weapon.

728 F.2d at 458 . On the issue of whether proof of this incident was sufficient to support municipal liability, the Tenth Circuit had this to say:

In this case the individual defendant had been on the police force for a very short period of time; moreover, he admitted his lack of training to cope with robberies. Nevertheless, he was allowed to go in on a suspected robbery by himself. Also, his gross failure to successfully handle the problem clearly demonstrated his complete lack of training and also his lack of ability. Thus the incident itself ... attested to the officer's lack of knowledge and ability. He claims to have considered Tuttle to be a robber but instead of pursuing him for the purpose of questioning, he fatally shot him without the least justifiable provocation. The ... rule [that a single incident is not adequate evidence to establish liability for inadequate training and supervision] is not to be considered as an absolute where the circumstances plainly show a complete lack of training.

728 F.2d at 461 . Justice Brennan accurately understood this reasoning as akin to the tort doctrine of res ipsa loquitur in that it would permit very strong circumstantial evidence to support a conclusion of fault and causation on the part of the city. But Justice Brennan did not believe that the circumstantial evidence was strong enough to support the inference in this case. $471 \mathrm{U} . \mathrm{S}$. at 831 n.6.

60. The district judge had acknowledged the impropriety under Monell of basing a judgment against the city on this sort of derivative liability, by his instruction to the jury that the city could not be held liable for the denial of a citizen's constitutional rights by a police officer "simply because of the employment relationship." 471 U.S. at 812 . 
the officer had been placed, with inadequate training and without any fault on his own part, in a frightening situation that he could not or did not know how to handle. If the plaintiff could establish that this was the case by evidence going beyond bare proof of the shooting, would that be enough to support a judgment against the city? ${ }^{61}$ That issue was addressed in a plurality opinion by Justice Rehnquist, writing for himself and three other Justices, ${ }^{62}$ and a concurring opinion written by Justice Brennan, for himself and two other Justices. ${ }^{63}$

Justice Brennan's opinion suggested that evidence of how an organization functions may be heard and is indeed essential if a case is to be made out against a municipality. He was concerned that "there may have been nothing that the city could have done to avoid" the incident, that it may have been "attributable to numerous . . . factors for which the city may not be responsible; the police officer's own unbalanced mental state [being] the most obvious example."64 What Justice Brennan would require is some direct evidence that a "particular action taken by the city" caused the deprivation of a constitutional right. ${ }^{65}$ This formulation leaves many questions unresolved. It is not at all clear, for example, whether Justice Brennan would be receptive to a claim that the structure of supervision in a police department made it likely that an officer in an "unbalanced mental state" would go undetected. ${ }^{66}$ But there is a strong suggestion in his opinion that, at least, the "substantial direct evidence concerning what [plaintiff] alleged to be the city's grossly inadequate policies of training and supervising police officers"67 would have been adequate if believed by a jury properly instructed. ${ }^{68}$ In this case, he stressed, plaintiff had pointed to

61. The plaintiff in Tuttle had offered such evidence, including testimony by an expert in police training practices that the Oklahoma City training curriculum was grossly inadequate. There was also evidence that Rotramel had had little or no training in when or how to handle a "robbery in progress" report, and Rotramel's own testimony that he had been inadequately trained. The problem for the Court was that, under the trial judge's instructions, the jury could have imposed "liability even if it did not believe [plaintiff's] expert at all." 471 U.S. at 822. Note that the interests of the city and the officer are in conflict if lack of training establishes both "official policy or custom" on the part of the city and a "good faith" immunity on the part of the officer, for the evidence that relieves the individual of liability overcomes the primary barrier to imposing liability upon the city.

62. 471 U.S. at 810.

63. 471 U.S. at 824.

64. 471 U.S. at 831 .

65. 471 U.S. at 829.

66. In Pembaur v. City of Cincinnati, 106 S. Ct. 1292, 1299 n.11 (1986), there is a strong indication that Justice Brennan would require much more than this. In that case Brennan says that "both the plurality and concurring opinions [in Tuttle] found plaintiff's submission inadequate because she failed to establish that the unconstitutional act was taken pursuant to a municipal policy rather than simply resulting from such a policy in a 'but for' sense."

67. 471 U.S. at 826.

68. The Court had hoped to address this issue in City of Springfield v. Kibbe, 55 U.S.L.W. 
a series of "conscious choices" made by the city that included official decisions concerning ... . : whether to permit rookie police officers to patrol alone; what rules should govern whether a police officer should wait for back-up units before entering a felony-in-progress situation; how much time and emphasis to be placed on training in such matters as how to approach felony-in-progress situations, when to use firearms, and when to shoot to kill. ${ }^{69}$

What is not clear is whether Brennan would be willing to describe less explicit decisions as "action[s] taken by the city."

Justice Rehnquist's view of what sort of evidence could be accepted was more narrow, and, as in Rizzo, he seemed to assume that the only proper way to evaluate the responsibility of a municipal defendant is to look for indicia of the sort of "state of mind" that marks out individual wrongdoers. Justice Rehnquist argued that the plaintiff must point to a conscious decision by an officer or a body of policymaking status. In this respect his opinion was similar to that written by Justice Brennan, but Rehnquist made it clear that he would require the plaintiff to point to something very deliberate and explicit. $^{70}$ And Rehnquist raised the possibility, explicitly rejected by Brennan, ${ }^{71}$ that it might not even be enough to show that that municipal decision has been the cause of a violation of the Constitution; Rehnquist suggested that the plaintiff might be required to show that the decision was itself unconstitutional. ${ }^{72}$ It is hard to say what this

4239 (U.S. Feb. 24, 1987). In Kibbe, the First Circuit, in an opinion by Judge Coffin, upheld a verdict against the city for the death of a fleeing motorist shot by a police officer during a highspeed chase. The court of appeals distinguished Tuttle on three grounds: There was no instruction allowing the jury to infer municipal policy solely froin the occurrence of the harm; plaintiff introduced sufficient evidence of gross negligence in failure to train police officers in how to conduct high speed chases; and the chase involved "at least ten officers and three separate shooting incidents, in which three different officers fired their weapons. ... This . . widespread activity ... is more likely to reflect the operating procedures of the police department than would a single incident such as occurred in Tuttle." Kibbe v. City of Springfield, 777 F.2d 801, 805-06 (1st Cir. 1985).

The defendant in Kibbe had argued below, and in its petition for certiorari, that a municipality could not be held liable, in a section 1983 action, for the inadequate training of its police officers. The Court, in granting the petition, had thought the case "fairly included" the related question whether something more than negligence would be required were liability for inadequate training to be allowed. After briefing and argument it became clear that the defendant had failed to object below to the trial court's conclusion that gross negligence was the appropriate standard to apply. Reluctant to resolve the general question of whether inadequate training could ever be the basis for municipal liability, without the opportunity to address the issue of the appropriate standard of care, a five-Justice majority concluded that the writ of certiorari should be dismissed as improvidently granted.

69. 471 U.S. at 829 n.4.

70. See 471 U.S. at 824 n.7.

71. 471 U.S. at 833 n.8.

72. 471 U.S. at 824 n.7. 
might mean: Does Rehnquist intend to limit liability to policies that are unconstitutional on their face?

What troubled Justice Rehnquist about the jury instructions in Tuttle was not simply that they allowed the jury to draw certain inferences about the state of the department's training on the basis of insufficient evidence. They also went too far in allowing inferences to be drawn about

the state of mind of the municipal policymakers. ... [M]ore importantly, the [instructions allowed the] plaintiff to establish municipal liability without submitting proof of a single action taken by a municipal policymaker. ... [A]t the least, [Monell's] requirement was intended to prevent the imposition of municipal liability under circumstances where no wrong could be ascribed to municipal decisionmakers. ${ }^{73}$

The word "policy," Justice Rehnquist went on to say, "implies a course of action consciously chosen from among various alternatives." Thus, "it is . . . difficult . . . to accept the submission that someone pursues a 'policy' of 'inadequate training,' unless evidence be adduced which proves that the inadequacies resulted from conscious choice that is, proof that the policymakers deliberately chose a training program which would prove inadequate."74

If this is to be the test of municipal liability - there is no discussion of the possibility that official "custom," as distinct from official "policy," may exist in the absence of a conscious decision by a policymaker - it will be very difficult to talk about harms done through inertia or mistake. It may be possible to talk about the unconscious and unconstitutional consequences of conscious decisions, but only if the Court does not require that the policy itself be unconstitutional on its face before it fulfills the requirement of Monell.75 And Justice Rehnquist's opinion indicates that the decisions at stake will only be those made at the most general level; he gave no attention to the possibility that liability could be based on the decision to send someone with Rotramel's training to respond to a report of a robbery in progress.

No Justice in Tuttle welcomed the possibility of looking with some

73. 471 U.S. at 821.

74. 471 U.S. at 823 . Now-Chief Justice Rehnquist joined in a dissent by Justice O'Connor from the Court's disposition of City of Springfield v. Kibbe, 55 U.S.L.W. 4239 (U.S. Feb. 24, 1987). In her dissent Justice O'Connor took the position that failure to train police officers "may serve as the basis for $\S 1983$ liability only where the failure to train amounts to a reckless disregard for or deliberate indifference to the rights of persons within the city's domain." 55 U.S.L.W. at 4242. In support of this conclusion, she referred to the common law's "willing[ness] to trace more distant causation when there is a cognitive component to the defendant's fault." 55 U.S.L.W. at 4242 . Justices Powell and White also joined the dissent.

75. See 471 U.S. at 824 n.7. 
flexibility into the effects of institutional structures. Justice Rehnquist explicitly rejected the possibility. Justice Brennan left it open in a narrowly written and cautious opinion. Justice Stevens, who filed a dissenting opinion, would have avoided the problem altogether by overruling Monell and allowing the plaintiff to proceed under the common-law regime of vicarious liability.

Tuttle held that a single instance of egregious unconstitutional conduct by a single front-line officer is not "official policy." More recently, in Pembaur v. City of Cincinnati, 76 the Court held by a vote of six to three that a single issue of explicit decisionmaking by an official in a relatively high municipal position could establish "policy" even though the decision was made in response to a discrete instance of confrontation between citizen and government. The explicit decision in Pembaur was made by a county prosecutor, who instructed deputy sheriffs to "go in and get" witnesses who were thought to be hiding behind a barricaded door in the office of the plaintiff, a doctor under indictment for welfare fraud. ${ }^{77}$ The day after the initial pleadings in Pembaur were filed the Supreme Court issued a decision ${ }^{78}$ accepting the plaintiff's theory that, "absent exigent circumstances, the Fourth Amendment prohibits police from searching an individual's home or business without a search warrant even to execute an arrest warrant for a third person."79 When Pembaur itself came before the Court, the only question left was whether the plaintiff had introduced sufficient evidence of "official policy" to allow the case against the county to survive dismissal.

The decision to allow the case to proceed established that Monell's reference to "policy" does not imply that the plaintiff must establish a pattern of recurring or repeated conduct. ${ }^{80} \mathrm{~A}$ single statement is adequate even if it does not purport to state what is generally appropriate. ${ }^{81}$ The Pembaur decision also established that a decision need not

76. 106 S. Ct. 1292 (1986).

77. $106 \mathrm{~S}$. Ct. at $1294-95$.

78. Steagald v. United States, 451 U.S. 204 (1981).

79. $106 \mathrm{~S}$. Ct. at 1295.

80. The Court was not presented with the issue whether such a pattern must be shown in order to establish official "custom."

81. Justice Brennan, for the Court, said that " 'official policy' often refers to formal rules or understandings ... that are intended to, and do, establish fixed plans of action to be followed under similar circumstances consistently and over time," as in Monell, but the term may also refer to "a course of action tailored to a particular situation and not intended to control decisions in later situations." $106 \mathrm{~S}$. Ct. at 1299. Indeed, in Owen v. City of Independence, 445 U.S. 622 (1980), discussed in text at notes 152-78 infra, the Court had found municipal liability to be appropriate even though a similar fact situation was unlikely to have occurred before or to occur again. In his dissent in Pembaur, Justice Powell described Owen as based on the formality of the procedures followed in reaching the government decision in Owen. $106 \mathrm{~S}$. Ct. at 1309. As my 
be written, or otherwise articulated for general consumption, in order to qualify as "official policy." The critical decision in that case consisted simply of a response to a question posed in a telephone conversation. (The deputies on the scene sought instructions from their supervisor, who told them to call an assistant prosecutor. The assistant then called the county prosecutor, who made the challenged decision.) ${ }^{82}$ What was most important to Justice Brennan, writing for the Court, was that the decision be "properly made by [the] government's authorized decisionmakers," that the "action [be] directed by those who establish governmental policy."83

Justice Brennan defined his task, as it was defined in Monell, to be the delineation of those "action[s] for which the municipality is actually responsible,"84 and "official policy" was, once again, described as the obvious alternative to the rejected theory of respondeat superior liability. The ability to point to a choice, a decision, by an individual with ultimate authority resolved the problem for the Court. ${ }^{85}$ But, by the time of Pembaur, it had become clear, as it should have been from the beginning, that defining "official policy" as the opposite of respondeat superior offers no simple solution to the problem of delineating what is the municipality's responsibility and what is the individual employee's. When Justice Brennan tried to explore Pembaur's implications for future cases, his majority dissolved into discordant voices, whose individual positions suggest that the elaboration of Monell will become increasingly tortuous.

Justice Brennan saw the critical step as finding a decisionmaker with sufficient authority to make choices for the municipality. When a decision is made by the local legislative body, ${ }^{86}$ the attribution of responsibility seemed, to him, to be easy. When other sorts of decisionmakers are involved, Brennan, joined by three other Justices, concluded that the question of authority to make policy is a question of state law. It then became dispositive that the court of appeals in Pembaur interpreted Ohio law to give the county prosecutor sufficient

discussion below indicates, however, the formal decision made in Owen was not in itself sufficient to create the constitutional injury alleged by plaintiff there. See text at notes 153-59 infra; see also note 87 infra (discussing Justice Brennan's statement that the official in question must at least have the authority to make generally applicable policy).

82. $106 \mathrm{~S}$. Ct. at $1294-95$.

83. $106 \mathrm{~S}$. Ct. at 1299.

84. $106 \mathrm{~S}$. Ct. at 1298.

85. In a part of the opinion joined by only three other Justices, Brennan suggested that "custom" may be established without evidence of such an affirmative decision. That question was not directly presented by Pembaur. 106 S. Ct. at 1299 n.10.

86. As, according to Justice Brennan, it was in Owen v. City of Independence, 445 U.S. 622 (1980), and in City of Newport v. Fact Concerts, Inc., 453 U.S. 247 (1981). 106 S. Ct. at 1298. 
authority to make county policy. ${ }^{87}$ Justice Powell responded, not unfairly, that this kind of analysis looks a great deal like respondeat superior liability, "at least with respect to a certain category of employees, i.e., those with final authority to make policy." $88 \mathrm{He}$ asserted that "no business organization or governmental unit makes binding policy decisions so cavalierly." 89 But the problem is not so much with Brennan's analysis as with the false promise of Monell. The true alternative to respondeat superior is not to search for those few officials whose actions can be described as "official policy," but to ask questions about how institutions can, as institutions, cause injuries.

Their own effort to make some sense of the dichotomy set up by Monell led two of the Justices who otherwise joined in the Brennan opinion to conclude that identifying a decision by an official with policymaking responsibility would not always be enough. Justice White and Justice $O^{\prime}$ Connor thought that Monell's reference to "official policy" required the court to evaluate the state of the law at the time of the challenged decision in the jurisdiction in which that decision was made. If the decision, even though made by the highest executive or legislative authority of a local governing body, violated federal, state, or local law at the time that it was made, that decision could not, according to White and O'Connor, be characterized as "official policy" - for "[w] here the controlling law places limits on their authority, [local officials] cannot be said to have the authority to make contrary policy."90 To hold otherwise, so that municipalities could be

87. In a footnote, Justice Brennan distinguished between giving an official, such as a sheriff, the "discretion to hire and fire," and giving that official the authority to "establish[] county employment policy." Only the latter would make that official's decisions municipal "policy." Thus, there would be no municipal liability for even an unconstitutional firing unless the decision to fire were made by an official or group of officials who had the authority to make general employment policy. $106 \mathrm{~S}$. Ct. at 1300 n.12. Here Brennan concluded that the prosecutor, although he had not made general policy in this case, had the authority to do so. $106 \mathrm{~S}$. Ct. at 1301 .

The application of this language in an employment case is before the Court in Praprotnik v. City of St. Louis, 798 F.2d 1168 (8th Cir. 1986), cert. granted, 107 S. Ct. 871 (1987).

88. 106 S. Ct. at 1308 (Powell, J., dissenting).

89. $106 \mathrm{~S}$. Ct. at 1308.

90. $106 \mathrm{~S}$. Ct. at 1301 (White, J., concurring). This argument is reminiscent of the fictional split between the exercise of official state power and the exercise of individual, private authority by one who holds a state position. That fiction was central to Ex Parte Young, 209 U.S. 123 (1908), in which the Court held that a suit seeking to enjoin a state attorney general from instituting proceedings to enforce a state statute that reduced railroad rates was not a suit against the state barred by the eleventh amendment, because

[t] he act to be enforced is alleged to be unconstitutional, and if it be so, the use of the name of the State to enforce an unconstitutional act ... . is a proceeding without the authority of and one which does not affect the State in its sovereign or governmental capacity. It is simply an illegal act upon the part of a state official in attempting by the use of the name of the State to enforce [an unconstitutional statute].

209 U.S. at 159. It is even more reminiscent of the arguments made by Justice Frankfurter, and 
held liable for "deliberate or mistaken acts [of officials] admittedly contrary to local law," would be to do what Monell forbids: to rest "on the basis of respondeat superior." 11 White joined in Justice Brennan's opinion because the forcible entry was not "illegal under federal, state or local law" at the time of the prosecutor's decision in Pembaur. ${ }^{92}$

Justice Powell, joined by Chief Justice Burger and Justice Rehnquist in dissent, placed exactly the opposite significance on the state of the law of the circuit at the time of the prosecutor's decision. Powell argued that there simply had been no violation of the Constitution because forcible entries without search warrants had been expressly approved by the federal court of appeals with jurisdiction over Ohio at the time of the decision. The question, he said, was whether to apply the Steagald ${ }^{93}$ decision "retroactively" 94 in a damage action brought for conduct occurring before Steagald had been announced. ${ }^{95}$ Powell

rejected by the Court, in Snowden v. Hughes, 321 U.S. 1, 17 (1944) (concurring opinion, in which Justice Frankfurter argued that there was no "state action" as required by the fourteenth amendment where the defendants had acted "in defiance of [their] duty ... . under [state] law," and that there could be no "state action" "until the highest court of the State confirms such action and thereby makes it the law of the State"), and in Monroe v. Pape, 365 U.S. 167, 240-41 (1961) (dissenting opinion, in which Justice Frankfurter argued that conduct cannot be said to be "under color" of state law within the meaning of section 1983 when it is "allegedly violative of federal constitutional rights, but plainly violative of state law").

Were the approach of Justices White and O'Connor to be accepted by a majority of the Court, it could mean that certain cases of first impression where the challenged municipal action violates state or local law would be difficult to bring to a federal court for decision on the merits. Where state or local law prohibits the conduct in question but there is no federal decision establishing its unconstitutionality, a damage action against an individual official defendant would be barred by Harlow v. Fitzgerald, 457 U.S. 800, 818 (1982), which protects individual officials who have not violated "clearly established . . . constitutional rights of which a reasonable person would have known." And an injunction action might be dismissed, under City' of Los Angeles v. Lyons, 461 U.S. 95 (1983), which denies standing to seek an injunction to those plaintiffs who cannot establish that they are likely to be future victims of the conduct sought to be enjoined. The White-O'Connor approach also, of course, makes the viability of section 1983 suits against municipal defendants vary according to the law of the municipality, state, and perhaps even circuit, in which the conduct occurred.

91. $106 \mathrm{~S}$. Ct. at 1302.

92. $106 \mathrm{~S}$. Ct. at 1301 . Justice $\mathrm{O}^{\prime}$ Connor went even further. She inferred the existence of official policy to engage in the challenged conduct from the fact that that conduct was not in violation of the applicable law: "Given that this procedure was consistent with federal, state and local law at the time the case arose, it seems fair to infer that respondent county's policy was no different [than the city's policy, which was conceded to be as plaintiff alleged]." $106 \mathrm{~S}$. Ct. at 1304 (O'Connor, J., concurring in part and concurring in the judgment).

93. Steagald v. United States, 451 U.S. 204 (1981); see text at notes $78-79$ supra.

94. Justice White left open the possibility that he would agree with this analysis. Like Justice Brennan, he did not reach the question of the retroactivity of Steagald on the grounds that it had been conceded by the county. See $106 \mathrm{~S}$. Ct. at 1302 n.*.

95. Note that this chronological sequence also provides the basis for a qualified immunity for the individual decisionmaker. He or she can be held liable in damages only for acts that violate constitutional rights that are clearly established at the time of the challenged action. Harlow $v$. Fitzgerald, 457 U.S. 800 (1982). 
concluded that Steagald should not be applied to Pembaur for two reasons. The first was his sense that constitutional cases against individual defendants involve unique notions of fairness ${ }^{96}$ beyond those at stake in actions for common-law torts: "Civil liability should not attach unless there was notice that a constitutional right was at risk."97 The second reason, fear of overdeterring law enforcement officers, combined the concerns Powell expressed in his opinion for the Court in Stone v. Powell ${ }^{98}$ with the desire, found in the cases involving individual immunities, 99 not to discourage vigorous executive action. Powell argued that section 1983 liability is primarily designed to deter, rather than to compensate; that local officials "are justified in relying on the judgment of the applicable federal court"; and that there is "nothing to deter" when there is "nothing that should have caused the officials to "harbor doubts about the lawfulness of their intended actions." "100

Both White's and Powell's approaches go beyond Brennan's in looking at the structure of incentives in the environment as a whole at the time of the challenged behavior. But both assume a consistency throughout the system - indeed, a reduction of the system to a single decisionmaker, the court - that overlooks the ambiguous ways in which government can operate. White would argue that once "the law" has been made clear by a court, the government cannot be considered responsible for any departures from that standard, however widespread, egregious, or authoritative those departures may be. Powell would relieve executive and legislative officials from any obligation to consider constitutional requirements once a court has spoken; he shows a concern that, at bottom, is still focused on the individual decisionmaker rather than the organization. ${ }^{101}$

The effort to distinguish constitutional torts from ordinary torts has led, in suits against individuals, to an insistence that the wrong be

96. See 106 S. Ct. at 1306 (citing Procunier v. Navarette, 434 U.S. 555, 562 (1978)).

97. $106 \mathrm{~S}$. Ct. at 1306.

98. 428 U.S. 465 (1976) (holding that fourth amendment exclusionary rule claims cannot normally be raised in federal habeas corpus because the additional deterrent effect that such an avenue of redress would afford is outweighed by the costs in excessive litigation and freeing the guilty). Pembaur, of course, is not an exclusionary rule case, so Stone is not directly applicable, and Justice Powell did not, in fact, refer explicitly to that case.

99. See, e.g., Harlow v. Fitzgerald, 457 U.S. 800, 814 (1982). Justice Powell cited Imbler v. Pachtman, 424 U.S. 409, 427-28 (1976) (prosecutorial immunity). Pembaur, 106 S. Ct. at 1306.

100. $106 \mathrm{~S}$. Ct. at 1306-07 (quoting Owen v. City of Independence, 445 U.S. 622, 652 (1980)).

101. For a discussion of Justice Powell's sensitivity to the position of those individuals who make up the government, and his inclination to view governmental actions as actions by individual decisionmakers operating in good faith to deal with difficult problems, see Whitman, Individual and Community: An Appreciation of Mr. Justice Powell, 68 VA. L. REv. 303 (1982). 
somehow more egregious than that ordinarily remedied through tort. That requirement has been carried over to suits against institutions, where an additional effort to distinguish constitutional torts has led to the rejection of vicarious liability. But without vicarious liability, some way of telling when an institutional defendant can be said to have caused harm by "its own violation" of constitutional norms is necessary. The Court has not devised a formulation that springs free of the language of individual wrongdoing. In Monell the question was easy because of the formal and explicit nature of the government rule under attack. The Court could evaluate the rule as it has become accustomed to evaluating legislative action embodied in statutes. When such a text is missing, the Court has searched for an individual with sufficiently high authority to "speak for" the government. The search for a mind to evaluate continues.

\section{The Pull of the Individual Model}

The effort to define the proper sphere for constitutional torts began with early efforts, not yet completely abandoned, to define a sufficiently egregious "state of mind" or "standard of care" to be applied to the individual officers named as defendants. Intent or deliberateness was often required. Once municipalities could be sued a similar approach took firmer root in cases against government defendants: those violations which are the government's "own," those for which it can appropriately be held to respond with damages or other relief, were defined as those that flow from choice or decision sufficiently deliberate to be called "official policy." This mode of analysis adopts tort concepts to evaluate questions that have not been posed in tort. It pushes the discussion into a search for a person whose mind or conduct can be evaluated in tort language and blinds courts to the ways in which harms can be caused by institutional structures and processes.

\section{A. Tort Analogies}

The Rizzo requirement of an "affirmative link" between the defendants' behavior and the plaintiff's injury, as applied to that case, seems to refer to common-law tort concepts of fault and causal connectedness, for tort provides the language that we use to attribute responsibility. It is this requirement of an "affirmative link" that "state of mind," "standard of care," and "official policy or custom" are meant to satisfy. To require the plaintiff to establish the defendant's "state of mind" - a particular intent, or attitude, or purpose - is to assume, quite literally, that the defendant will have a mind to evaluate. Presumably the mind is that of a designated official; there are obvious 
problems with finding where mind lies when the defendant is a government. When the requirement is put in terms of "standard of care" the problems are somewhat, but not entirely, different. At first glance it is not absurd to argue that section 1983 requires, even in actions against municipalities, something more than mere negligence, the violation of a more stringent standard of care than that applied in the routine common-law tort. 102 Negligence is, first-year law students are taught, an "objective" standard, necessarily an evaluation of the defendant's conduct rather than of her mind. ${ }^{103}$ But negligent conduct may be said to be wrongful because of the attitude that it suggests, and in that sense an inquiry into the existence of negligence ultimately also refers to the evaluation of a mind. Whether analyzed as a moral or an economic injunction, ${ }^{104}$ negligence in tort is at root a variously elaborated requirement that the injurer take some care to anticipate the potential victim's interests and consider them sympathetically. 105 It imposes, in a sense, a standard of empathy: We must weigh each other's interests as our own. It requires a reciprocity of concern. Another way of putting this, perhaps more congenial to economists, is that we must evaluate proposed conduct from a disinterested perspective, a perspective in which all merely personal choices are assumed to be of equal value. We are, it seems, still talking about a way of thinking. But, again, do institutions think?

Appropriately, the Supreme Court has never accepted a general requirement that something more than negligence be established in order to bring a claim under section 1983 against either municipal or individual defendants. ${ }^{106}$ The statute, as the Court has understood, provides a remedy for wrongs defined elsewhere; it does not establish substantive requirements of its own, other than that the violation of federal rights be "under color of" state or local law. 107 But when the Court has looked elsewhere for the definition of those wrongs sought to be remedied in section 1983 litigation, it has often read specific constitutional provisions to include a "state of mind" requirement, to pro-

102. See text at notes 19-20 supra.

103. See 3 F. HARPER, F. JAMES \& O. GRAY, supra note 8 , $\$ 16.2$, at 390-93; O.W. Holmes, supra note 7 , at $107-09$.

104. Compare O.W. Holmes, supra note 7, at 92-95, with Posner, A Theory of Negligence, 1 J. LEGAL STUD. 29, 32-33 (1972).

105. Cf. Schwartz, Contributory and Comparative Negligence: A Reappraisal, 87 YALE L.J. 697, 702-03 (1978); J. O'CONNELI, ENDING INSULT TO INJURY 199-200 (1975).

106. This possibility was explicitly rejected in Parratt v. Taylor, 451 U.S. 527, 534-35 (1981), and the rejection was reaffirmed in Daniels v. Williams, $106 \mathrm{~S}$. Ct. 662 (1986), which overruled Parratt's conclusion that negligent takings were "deprivations" for purposes of the fourteenth amendment's due process clause. See text at notes 194-221 infra.

107. Parratt v. Taylor, 451 U.S. 527, 535 (1981). 
hibit only government action taken with a specific, improper purpose or attitude. The eighth amendment, for example, has been interpreted to prohibit only actions that indicate "callous indifference" to the rights of others. ${ }^{108}$ And the equal protection clause has been read to require an "intent to discriminate." 109 In these cases, the Court has not only required a showing of something more than negligent conduct, it has created a kind of "intentional tort" that is much more difficult to establish than any such tort at common law precisely because it requires evaluation of actual state of mind rather than of conduct as a clue to that mind.

One reason why it might have seemed plausible to ask whether something more than negligence must be proved in a constitutional case is that, to the extent that there are tort analogies to constitutional cases, they most often come from intentional torts. But even wrongs that can be described as trespass, ${ }^{110}$ assault and battery, ${ }^{111}$ false imprisonment, ${ }^{112}$ or defamation ${ }^{113}$ take on new urgency when the defendant is the government. When the government is the wrongdoer, ordinary injury is augmented by the abuse of government power, and the Constitution has appropriately been read to address these augmented injuries in their own terms, rather than by analogy to common-law torts. ${ }^{114}$

When the Court requires the plaintiff to establish that the defendant had an intent to discriminate in an equal protection case, ${ }^{115}$ or finds dispositive an intent to penalize the exercise of speech in a first

108. Estelle v. Gamble, 429 U.S. 97 (1976). When evaluating the use of force during a prison disturbance, the standard is even higher: The eighth amendment is violated only when the force was not "applied in a good faith effort to maintain or restore discipline [but used] maliciously and sadistically for the very purpose of causing harm." Whitley v. Albers, $106 \mathrm{~S}$. Ct. 1078, 1085 (1986) (quoting Johnson v. Glick, 481 F.2d 1028, 1033 (2d Cir.) (Friendly, J.), cert. denied, 414 U.S. 1033 (1973)).

109. See, eg., Village of Arlington Heights v. Metropolitan Hous. Dev. Corp., 429 U.S. 252, 264-65 (1977); Washington v. Davis, 426 U.S. 229, 239-41 (1976). See also the discussion in text at notes 194-221 infra of Daniels v. Williams, 106 S. Ct. 662 (1986), and Davidson v. Cannon, 106 S. Ct. 668 (1986); in those cases, the Court held that the due process clause addresses only intentional deprivations of life, liberty, or property.

110. E.g., Monroe v. Pape, 365 U.S. 167 (1961).

111. E.g., Rizzo v. Goode, 423 U.S. 362 (1976).

112. E.g., Baker v. McCollan, 443 U.S. 137 (1979).

113. E.g., Paul v. Davis, 424 U.S. 693 (1976).

114. Cf. Monroe v. Pape, 365 U.S. 167, 196-98 (1961) (Harlan, J., concurring) (noting that a "state-approved" constitutional deprivation seems more offensive than a state tort). The inclination, found in some early lower court opinions, e.g., Whirl v. Kern, 407 F.2d 781 (5th Cir. 1969), to resolve section 1983 disputes solely by reference to the elements of common-law causes of action has virtually disappeared.

115. See Washington v. Davis, 426 U.S. 229, 239-40 (1976). 
amendment case, ${ }^{116}$ it is looking for motive, for the purpose behind the act $^{117}$ - an inquiry that is irrelevant to intentional tort at common law. ${ }^{118}$ The intent that triggers liability at common law represents a cruder attempt to detect those who harbor an improper attitude toward those around them. As in negligence, the improper attitude is assumed from the consequences. And those consequences need not support an inference of ill will or nefarious purpose; it is sufficient that they support an inference of intent to touch the person or property of another (or to move your body in a way that is "substantially certain" to result in such a touching).119 The constitutional requirement more deliberately and directly penalizes the defendant's attitude toward the plaintiff.

This emphasis on attitude and purpose, while it may be a troubling limitation in constitutional litigation generally, is nonsense in suits against defendants who are governments, for it focuses precisely on that element that exists in individuals but not in institutions - on mind. It is not that "mere negligence" should be enough to state a constitutional case, ${ }^{120}$ but that to ask about negligence, at least as a reflection of attitude or motive, is to pose the wrong question. When the defendant is an institution it has no human face. ${ }^{121}$ It is not surprising that the plaintiff may often see herself as an asserter of rights with no corresponding obligation in return. ${ }^{122}$ The root legal obligation cannot be defined in terms of empathy or mutual care. That cast of mind, implicit in many formulations of the negligence requirement, makes no sense when the defendant is necessarily not an individual, but an institution or its representative. There is no mind, and no possibility that she who sues as plaintiff could stand in the place of the defendant.

There is another way to read common-law negligence that makes no claim to evaluating mind. In this reading, negligent behavior is "at

116. See Minneapolis Star \& Tribune Co. v. Minnesota Commr. of Revenue, 460 U.S. 575, 579-80 (1983).

117. See, e.g., Village of Arlington Heights v. Metropolitan Hous. Dev. Corp., 429 U.S. 252, 265.66 (1977) (judicial deference is unnecessary "[w] hen there is a proof that a discriminatory purpose has been a motivating factor in the decision").

118. E.g., Vosburg v. Putney, 80 Wis. 523, 50 N.W. 403 (1891).

119. E.g., Garratt v. Dailey, 46 Wash. 2d 197, 279 P.2d 1091 (1955); Vosburg v. Putney, 80 Wis. 523, 50 N.W. 403 (1891).

120. Parratt v. Taylor, 451 U.S. 527, 532 (1981).

121. This is not the case when the defendant is a named police officer or other relatively lowlevel government agent. In those cases, the plaintiff and the defendant can both be described as people subject to worry and institutional pressures. See P. ScHUCK, SUING GoVERNMENT 59-81 (1983); Whitman, Constitutional Torts, 79 Mich. L. Rev. 5, 56-62 (1981).

122. See, e.g., M. Shapo, The Duty to Act: Tort Law, Power \& Public Policy (1977). 
fault" and sufficient to trigger the responsibility to make an injured plaintiff whole because it is inefficient and wasteful of society's resources. As described by Judge Learned Hand ${ }^{123}$ in terms enshrined by Judge Richard Posner, ${ }^{124}$ tort liability sanctions negligence in order to provide incentives to engage in less wasteful behavior. It encourages actors to evaluate the risks and gains of various courses of conduct from the perspective of all those potentially at risk and to avoid those activities in which "the benefits in accident avoidance exceed the costs of prevention."12s There is some strain in applying this concept to individual behavior. If the standard upon which liability turns is not to be unduly harsh, there must be some fair expectation that potential defendants can and should act reasonably, that failure to do so is sufficiently aberrant to call forth heavy sanctions when another is injured. This expectation, applied to ordinary human conduct, may be unrealistic. We all act unreasonably much, perhaps most, of the time. By this I do not mean to say that rational behavior never occurs - I hope that it is not infrequent. My point is, rather, that the negligence standard is high and the failure to meet it is not always, or even typically, due to aberration or moral failure in any obvious or natural sense. Accidents are seldom simply the result of egregious carelessness or any other behavior that we can easily condemn as morally wrong. Physical incapacities, fatigue, inattention, preoccupation, and stress play a role. The rule of negligence sets a standard that none of us is capable of meeting much of the time. It is no answer to allow excuses for physical incapacity and other hindrances to rational behavior. Even if they could be the subject of proof, physical incapacities cannot be easily distinguished from those mental incapacities that affect the actor's ability to understand and conform to norms. And allowing excuses for mental incapacities of this sort calls the entire enterprise into question, for incapacity in this sense cannot in practice be neatly separated from the deliberate refusal to accept others' values. ${ }^{126}$ Our very ability to perceive and participate in the standards of the community in which we live varies from individual to individual in a manner inaccessible to evaluation by a court.

It might be argued that the negligence standards devised by tort law - even though they have been developed in response to questions about individual obligations and the propriety of specific, rather finite

123. United States v. Carroll Towing Co., 159 F.2d 169 (2d Cir. 1947).

124. Posner, supra note 104, at 32-33.

125. Id. at 33.

126. See Henderson, Process Constraints in Tort, 67 CoRnell L. Rev. 901,912 \& n.52, 920 n.89 (1982). 
behavior - are particularly well-suited to evaluating the conduct of institutions once those standards are broken free from the concept of mind and only address behavior. Institutions, the argument would go, may be more able than individuals to make sophisticated analyses of the risks of courses of conduct. This is so because organizations, especially those organizations that engage in repetitive risky behavior, possess the resources to acquire large amounts of information over time and to hire employees with the training and expertise necessary to assess risk. To the extent that the negligence test is an effort to capture inefficient activities, it may seem to be most fairly applied to institutional actors, who are in the best position to perform the comparison of costs that the formula requires. ${ }^{127}$ Indeed, strict liability, if imposed to provide a practical assurance that an actor will fairly evaluate the interests of others before she acts, ${ }^{128}$ may be most appropriately applied to institutional actors for the same reason.

But even so formulated, negligence language, although it might make most sense when applied to institutions rather than to individuals, does not seem adequate to the task of charting institutional responsibility for injuries. The common-law negligence test as it has been applied, even in cases of institutional defendants, focuses on isolated decisions and isolated injuries. It overlooks issues that are unique to institutional behavior - for example, problems of massed power, of cumulative injury, and social planning. And, institutions are not immune from the problems of lack of information and incompetence that afflict individuals. The actors that compose institutions are individuals, and even in groups individuals may act in ways that reflect stupidity or inattention. In fact, institutional structures may create their own pressures toward "nonrational" or wasteful behavior. An employee may prefer inaction because that is least likely to get her into trouble. ${ }^{129} \mathrm{Her}$ desire to please her superiors, impress her peers or put her subordinates in their place may lead her to rash and foolish, or simply evasive, behavior. Those in the position to set policy may find

127. Cf. Rodgers, Negligence Reconsidered: The Role of Rationality in Tort Theory, $54 \mathrm{~S}$. CAL. L. REv. 1, 12-13 (1980) (even the most rational actors cannot be aware of, and take steps to prevent, "highly improbable risks beyond the range of the rational calculus").

128. An argument for strict liability is that the courts cannot make an accurate cost-benefit analysis in every case. If they could, the threat of liability for negligence would be sufficient to encourage efficient behavior, for inefficient behavior would subject an actor to liability. See Posner, supra note 104 , at $32-33$. To the extent that courts cannot accurately detect inefficient behavior and therefore let some such behavior go unsanctioned, the incentives provided by the negligence system are imperfect. Strict liability places all costs on the actor, whether his behavior is inefficient or not. He then has an incentive to act efficiently in order to minimize the costs to himself, for he will bear them all.

129. See P. SchUCK, supra note 121 , at 71-73. 
it easiest to overlook the misconduct of their subordinates. (Perhaps this is what happened in Rizzo.) The injury may be made much greater by the simultaneous or cumulative acts of several departments unaware of the steps being taken by each other, accidental injury may be the consequence of a series of decisions made by several employees, no one of whom perceived the whole and understood the risk being run. ${ }^{130}$ If institutions are to be held liable for these injuries it is because concepts of fairness in attribution of responsibility that have been developed for individuals are not applicable in imposing liability upon institutions. But the greater danger of our lack of language unique to institutional responsibility is that, by focusing only on one incident of decisionmaking or injury, injuries caused by institutional structures will not even be perceived.

\section{B. The Alternative}

The Supreme Court's response to these dilemmas, in the decisions described above, was not to move beyond casting the evaluation in terms of individual wrongdoing, but to look for an individual (or individuals) who could be analyzed in the government's stead because he could be said to act for the government. In addition, it was assumed without discussion that government acts as government only when it plays the role of decisionmaker, or legislature. So the inquiry took the form of a search for those persons, and those legislative bodies, who make decisions: government "policy or custom" was "made by [a local government's] lawmakers or by those whose edicts or acts may fairly be said to represent official policy."131 Much of the post-Monell litigation has revolved around the question of whether a particular official had sufficient status and authority to act as a decisionmaker for a municipality. ${ }^{132}$

After Monell the Court was caught between its commitment to the rejection of government liability "for an injury inflicted solely by its employees or agents," 133 and the only language it possessed for ascribing responsibility for injuries - tort language which describes wrongdoing and causation in terms that were devised for the actions of individuals. The Court had no language for describing how an institu-

130. One of these possibilities may explain what happened in Owen v. City of Independence, 445 U.S. 622 (1980); see notes 152-78 infra and accompanying text.

131. Monell v. Department of Social Servs., 436 U.S. 658, 694 (1978).

132. See, e.g., Bennett v. City of Slidell, 728 F.2d 762 (5th Cir. 1984), cert. denied, 472 U.S. 1016 (1985); McKinley v. City of Eloy, 705 F.2d 1110 (9th Cir. 1983); Berdin v. Duggan, 701 F.2d 909 (11th Cir.), cert. denied, 464 U.S. 893 (1983); Brewer v. Blackwell, 692 F.2d 387 (5th Cir. 1982).

133. 436 U.S. at 694. 
tion or a government uniquely acts, so it looked to acts, such as passage of ordinances or regulations, or decisions by those with a very high level of authority, that, in essence, label themselves as institutional or governmental. There must, the Court seems to have decided, be some formal decision of this sort. To count every official's decisions as forming government "policy" would be tantamount to imposing respondeat superior liability. "Official policy or custom," defined as conscious choices made by high-level decisionmakers, seemed the only option between vicarious liability and no liability.

There are other alternatives. The Court in Monell implicitly referred to some of them in describing the extraordinary reach of the first conference substitute for the amendment proposed by Senator Sherman. That proposal

imposed liability on the government defendant whether or not it has notice of the impending riot, whether or not the municipality was authorized to exercise a police power, whether or not it exerted all reasonable efforts to stop the riot, and whether or not the rioters were caught and punished. ${ }^{134}$

Under a statute that, unlike the proposed amendment, accepted these limitations on municipal liability, a government could still be held liable for conduct that did not involve an official decision to act. That is, the municipal defendant could be held liable for those cases in which it had notice of an impending riot and possessed the power to stop it; yet reasonable preventative steps were not taken and the rioters escaped. Liability could be imposed in such a case - whatever the source of the failure, be it an official decision to turn a blind eye to the riot or simply excessive diffusion of responsibility - without encroaching on the concerns implicit in Congress' rejection of the Sherman amendment.

The Court's formulation ignores this option. It requires a decision. Caught by the language of tort, the Court apparently has concluded that liability based on, for example, cumulative inattention, or diffusion of responsibility, would be inconsistent with Rizzo v. Goode's insistence on an "affirmative link" between individual victim and individual wrongdoer, the precursor of Monell's rejection of vicarious liability. ${ }^{135}$

But the assumption that all categories of liability must be divided into either vicarious liability or affirmative decisions is not even supported by tort law as applied to individuals, ${ }^{136}$ and it is particularly

134. 436 U.S. at 668.

135. 436 U.S. at 692 ; see also 436 U.S. at 694 n.58.

136. Some of the alternatives to vicarious liability in tort - such as liability for intentional torts, which requires an intent to make a specified wrongful incursion on another's person or property, or strict products liability, which requires a decision to engage in the business of selling 
strained and inappropriate in discussing the injurious effects of institutions. Even if individual liability for constitutional torts could be fairly limited to affirmative misbehavior, institutions occupy space in the world in a different way than individuals do, and the consequences, both beneficial and harmful, of their actions are created differently. The shape and the existence of institutional bodies are the result of choices that continue over time and that can be modified. This is simply not true in the same way of individuals. Institutions "think" differently, or, more accurately, they don't think at all, yet they create consequences. In evaluating individual liability, AngloAmerican tort law has not as a general rule held defendants liable for omissions, for failures to act.137 This seems to have been what concerned the Court in Rizzo, ${ }^{138}$ and again in Monell. ${ }^{139}$ But institutions do something "affirmative" by simply existing, and, unlike individuals, they can change their form of existence or simply cease to exist.

One does not exhaust what an individual is and does by looking only to declared purposes and intent. That is even more true of organizations. I have suggested some of the problems above: Institutions cause consequences even through diffusion of responsibility. Or through common practices that are widespread but do not "have the force of law" and may even be flatly prohibited by "official" regulations. And there are structural disincentives to take action or to see problems, and, more affirmatively, communal mores or fellow feelings that lead those within an institution to rank the interests of each other higher than the interests of those outside. At the least, we cannot be as confident as the Court seems to be that the language of choice and intent and motive is adequate for evaluating the behavior of governments.

One danger of a narrowed inquiry into government responsibility is that it will prevent the Court from recognizing that consequences may be created over time, or that several branches of a government may work together to create a constitutional tort where no such tort would exist were the activity of only one branch considered. The Court has not been completely unwilling to evaluate the way in which an institution functions as a whole or over time. But the most obvious example of such thinking - the school desegregation cases following

a particular product - do require proof of a particular sort of decision. But negligence, although it can be applied to conduct flowing from a decision, does not ask whether a decision to act (or fail to act) in a certain way has been made.

137. See, e.g., Buch v. Amory Mfg., 69 N.H. 257, 44 A. 809 (1898).

138. 423 U.S. at $370-71$.

139. 436 U.S. at 692 (citing Rizzo). 
Brown v. Board of Education 140 - reveals an entrenched unwillingness to follow such an approach to its conclusion. In the desegregation cases the Court, although requiring evidence of a deliberate discriminatory decision made by the board defendants, ${ }^{141}$ has evaluated each district's school board as an ongoing institution. A conclusion that the Constitution has been violated can be reached on the basis of acts of deliberate segregation committed by members whose service ended years before, and once such a conclusion has been reached it will support an order that remedial steps be taken by current board members who themselves have made no discriminatory decisions. ${ }^{142}$ But this step was relatively easy - the board could still be described, by analogy to an individual and like a legislature, as a single maker of formal decisions. Once a finding has been made that a board, albeit in an earlier incarnation, has unconstitutionally discriminated, the remedies for this discrimination have been broadly crafted to create a functioning desegregated system ${ }^{143}$ - a goal that necessarily requires a broad view of how the structure of schools within a district might best work to minimize the effects of past segregation. Aside from the remedial implications and the willingness to consider a school board as a single institution over time, rather than as a shifting group of individuals, these decisions break no very significant ground. In their refusal to reach de facto segregation the decisions retain the basic requirement that one individual, or a group of individuals, be shown to have made a decision motivated by an unconstitutional intent to discriminate on the basis of race. Even if the evaluation can extend back in time, the requirement that a particular state of mind be established in an identifiable individual or individuals remains. These cases are, from that perspective, quite consistent with the Court's insistence on reducing the question of institutional responsibility to one of individual wrongdoing. They represent no true alternative, but they suggest that movement away from the individual model is not impossible.

\section{Implications}

If it were to pursue seriously the matter of how an institution functions as a whole, the Court would have to ask questions that have no

140. 347 U.S. 483 (1954).

141. In Keyes v. School Dist., 413 U.S. 189 (1973), a majority of the Court rejected de facto segregation as a basis for finding that the equal protection clause had been violated.

142. See Columbus Bd. of Educ. v. Penick, 443 U.S. 449 (1979); Swann v. Charlotte-Mecklenburg Bd. of Educ., 402 U.S. 1 (1971).

143. Penick, 443 U.S. at 458-61; Swann, 402 U.S. at 13, 15-16. 
parallel in cases involving individual wrongdoing: Does the institution's structure encourage or discourage adherence to constitutional standards of behavior? Does the institutional arrangement conceal consequences or dilute responsibility in a way conducive to unconstitutional behavior? One of the consequences of this change in attention might be an expansion of what constitutes redressable harm. In the constitutional context, the harms in question are often something other than obvious physical injuries. ${ }^{144}$ The terms of the Constitution, read with an increased awareness of the ways in which governmental power is felt by citizens, draw our attention to nonphysical harms: emotional injuries, cumulative injuries inflicted by many small acts over time, and the more tenuous economic injuries, such as decreased opportunities for education or employment. ${ }^{145}$ Injuries of this sort may be attributed to institutional behavior only as courts become more sophisticated in tracing its effects; they may be easy to see only when courts stop searching for an identifiable individual decisionmaker.

Thinking about institutions as institutions breaks the model of reciprocal responsibility that is the basis of the common law. The language of common-law tort presumes that each litigant is potentially both plaintiff and defendant; the defendant is, at least theoretically, held only to those standards that could also be fairly applied to the plaintiff were their positions reversed. When the question of responsibility is not defined in terms of the reciprocal obligations of potentially equal individuals, it becomes possible for the plaintiff to ask that her interests be taken into account by the defendant to an even greater degree than has been required by the common law. She may also believe, and the judge may agree, that a government defendant can fairly be required to be more responsive to broad community values in a way that would be an inappropriate imposition on private or individual conduct, for the government is charged to reflect the goals of society as a whole rather than the narrower self-interest permitted private actors. ${ }^{146}$ At most, the redefinition of responsibility may take the form of a demand that the plaintiff be provided for, protected, maintained in

144. See, e.g., Monell v. Department of Social Servs., 436 U.S. 658 (1978); Carey v. Piphus, 435 U.S. 247 (1978); Burton v. Wilmington Parking Auth., 365 U.S. 715 (1961); Brown v. Board of Educ., 347 U.S. 483 (1954).

145. See, e.g., Brest, The Supreme Court, 1975 Term - Foreword: In Defense of the Antidiscrimination Principle, 90 HARV. L. REv. 1, 8-12 (1976).

146. Of course, if society's goals are taken to be simply the achievement of efficiency, private enterprises, rather than government institutions, may most closely reflect the public interest. See Kornhauser, An Economic Analysis of the Choice Between Enterprise and Personal Liability for Accidents, 70 CALIF. L. REv. 1345, 1376-78 (1982). 
a certain state of security and well-being. ${ }^{147}$ At the least, it leads to a demand for dignity - for fair consideration of one's concerns and interests, as at common law, but with specific and visible guarantees to assure the supplicant that the process is indeed fair; for freedom from stigma or improper categorization; for freedom to exercise certain rights, such as free speech or privacy. It goes too far to say that citizens are owed absolute protection from harm, or a minimum guarantee to the good life, from those who hold power, ${ }^{148}$ but there are injuries that may properly be the focus of litigation even though they cannot be analyzed by traditional tort doctrine.

If the court were to break free, in constitutional litigation (and perhaps in litigation against other sorts of institutions), from evaluating the defendant's acts as if they were the product of an individual mind, one consequence would be to bring to the fore the irrelevance of the categories of intent, negligence, and even strict liability derived from tort. ${ }^{149}$ Nor should that other indicia of "mind" - a formal decision - be required. The government, like other institutions, operates through structures that direct and dispose of power. These can injure grievously when deliberately used by individual human beings to do harm. And they can injure just as seriously through inertia, direction of energy to narrow goals, and oversight in the design of institutional structures. It is in this sense that focus on institutional structures may expand our sensitivity to previously disregarded harms. It may lead us to be more appreciative of the positions of some defendants as well. For example, when the defendant is in fact an individual, rather than an institution, an awareness of institutional structure, and of the incentive systems which that structure creates, may lead us to be more tolerant of the individual's oversight, lack of imagination, or failure to take care. ${ }^{150}$

Even when the defendant is the government, or any institution of

147. See, e.g., Michelman, States' Rights and States' Roles: Permutations of "Sovereignty" in National League of Cities v. Usery, 86 YALE L.J. 1165 (1977); Tribe, Unraveling National League of Cities: The New Federalism and Affirmative Rights to Essential Government Services, 90 HARV. L. REv. 1065 (1977).

148. Whitman, $A$ "Humanitarian" Approach to Individual Injury, 79 MrCH. L. REV. 762, $765-67$ (1981).

149. "Strict liability" is a term used to distinguish those theories of liability that do not inquire into whether the defendant has acted reasonably or with negligence. It is useful, then, for discussing whether negligence or some other theory should be used to determine liability in tort. But negligence, to the extent that it embraces an obligation of empathy or mutual care, is not a coherent way of talking about the exercise of institutional authority, and, therefore, the question whether negligence or some other, strict liability theory should be used does not produce a useful inquiry. See text at notes 120-22 supra. For the relevance of other, more explicitly economic concepts of negligence, see text at notes 123-28 supra.

150. See P. SchUCK, supra note 121, at 59-81. 
great power and complexity, it may not be fair to expect strict compliance with the obligation (whether embodied in tort law or in constitutional provisions) to consider the impact of one's activities on the interests of others. The scope of potential victims may include all of society, and the capacity of even a large and well-run institution to take all the relevant interests into account has limits. Damages as the price of failure may be too high. Yet, the price paid by the victim may also be severe and one for which it is indeed appropriate to hold the institution responsible. Moral evaluations of conduct, which are often used to justify the imposition of liability on individual defendants, need not be the sole basis of institutional obligation, particularly if the remedy is an injunction to take care rather than an order to pay damages. ${ }^{151}$ If this is what "responsibility" entails, it may have more to do with an assessment of the severity of the plaintiff's injury, and the conclusion that it may be avoided or reduced by the defendant, than with any evaluation of the "morality" of the defendant's acts. The point would be that there are certain harms that institutions should not inflict, or should pay for, or should make special efforts to minimize - rather than that a wrong decision has been made or wrongful conduct undertaken.

\section{The Alternative Applied}

The very difficulty of formulating a vocabulary of responsibility that is not derived from tort suggests that the courts might be wise to avoid taking on the task of tracing the consequences of institutional structures and processes. Yet in some cases it has seemed most natural to think of the institution as a whole in attributing responsibility for harms. In these cases the Court's first instinct has been to frame the question in terms that break away from tort, and only as an afterthought has the language of tort exerted its pull. The cases do not engage in the full analysis of structure and context suggested above, but they do provide some indication that the Court's difficulties in articulating a theory of institutional responsibility are due to habits of language that can be overcome. One example can be found among the "official policy and custom" cases. The more imaginative efforts to think about these questions anew are found in cases involving due process claims, and it is from one of these efforts that the Court has retreated most dramatically.

151. See Whitman, supra note 121 , at $41-67$. 


\section{A. Institutional Wrongs: Owen}

Owen v. City of Independence ${ }^{152}$ indicates that, at least when there are explicit, decisive, and virtually contemporaneous actions by several top decisionmakers, the Court will recognize that several branches of the government, working together, can create a constitutional tort even though the action of any single branch is not by itself unconstitutional. Owen was an action brought against the city and several officials in their official capacity. The plaintiff was a former chief of police who had been publicly charged by the city council with abuse of his position and fired by the city manager on the following day. The case was complicated by evidence that the manager had made the decision to fire Owen before the council resolution and by the absence of any stated grounds for the termination other than a reference to a city charter provision that gave the manager sole authority to remove department heads. There was no indication that the city manager and the council had jointly planned the sequence of events. The court of appeals, applying Monell, held that the circumstances of the discharge had inflicted an injury to Owen's reputation that "was caused by the official conduct of the City's lawmakers ... [ [and] amounted to official policy," depriving him of a protected liberty interest. ${ }^{153}$ There was no cross-petition by the city challenging this conclusion that Owen had been deprived of a "liberty" interest, so it was not properly before the Court. But Justice Brennan, writing for the majority, took the time in a footnote to state that "[w]e find no merit" in the city's contention that there was no deprivation of a protected interest. ${ }^{154}$ The problem was that no protected interest would have been impaired had the discharge occurred without any damage to plaintiff's reputation, ${ }^{155}$ and damage to reputation alone also does not implicate any constitutionally protected interest. ${ }^{156}$ In Owen's case, the manager performed the discharge, while the council issued the allegedly defamatory statements. ${ }^{157}$ Neither act, standing alone, amounted to a violation of the Constitution. Justice Brennan, however, saw no barrier to recovery: "[T]he city - through the unanimous resolution of the City Council - released to the public an allegedly false statement impugning petitioner's honesty and integrity. Petitioner was discharged the next

152. 445 U.S. 622 (1980).

153. 589 F.2d 335, 337 (8th Cir. 1978).

154. 445 U.S. at 633 n.13.

155. Bishop v. Wood, 426 U.S. 341 (1976).

156. Paul v. Davis, 424 U.S. 693 (1976). 1976).

157. The district court thought this dispositive. 421 F. Supp. 1110, 1121-22 (W.D. Mo. 
day. ... [T] cur[red] in the course of the termination of employment." "158 The Court, then, refused to divide the city of Independence into separate decisionmakers (the council and the manager) and require that one of these be found to have acted unconstitutionally. ${ }^{159}$ It emphasized, instead, the effect on the plaintiff of the city's actions, taken as a whole. It was enough that Owen had suffered an injury that would clearly implicate the Constitution had it been solely the result of either the manager's or the council's actions. Yet, the Court still thought it significant that both parts of the city government had issued overt and explicit announcements that decisions had been made. Both the manager's written notice discharging the plaintiff and the council's resolution fit easily with the language of purpose and decision devised in Monell. ${ }^{160}$ Under those circumstances the Court thought it fair to hold the city accountable. ${ }^{161}$ (It may also have been important that Owen could point to a subsequent decision that could be described as the unconstitutional act of a single actor: after the discharge, at a time when all were aware of the Council's actions, the city refused a demand from Owen for leave to appeal the discharge decision. ${ }^{162}$ )

However, in addressing the question upon which certiorari had been granted - a question of remedy, rather than of defining the wrong - Justice Brennan, writing for the Court, moved away from the analogy to individual responsibility that underlay Rizzo and Monell. Owen sought declaratory and injunctive relief, including a hearing, backpay, and attorney's fees, but during the course of litigation he reached the age of mandatory retirement, so his claim eventually re-

158. 445 U.S. at 633 n.13 (quoting Paul v. Davis, 424 U.S. 693, 710 (1976)).

159. Justice Powell took the opposite view in dissent. He thought that "[t]he notoriety that attended Owen's firing resulted not from any city policy, but solely from public misapprehension of the reasons for a purely discretionary dismissal." The fact that the misapprehension was also caused by city action was irrelevant; indeed, Powell thought it was attributable, not to the city, but to "the unauthorized statements of a lone councilman who had no direct role in the discharge process. . . . There was [therefore] no constitutional injury . . .." 445 U.S. at 664 .

160. Justice Brennan pointed out that the allegedly defamatory statements were released to the public "through the unanimous resolution of the City Council." 445 U.S. at 633 n.13. In Pembaur, Brennan erroneously described Owen as a case in which the "city council passed [a] resolution firing plaintiff without a pretermination hearing." Pembaur v. City of Cincinnati, 106 S. Ct. 1292, 1298 (1986).

161. The questions of "official policy or custom" and whether there has been a constitutional violation become intertwined here, as they often are, because both raise the issue of how broadly the Court will look in tracing the causal connections between the defendant city and the plaintiff's injury. Justice Powell's response to Justice Brennan, see sote 159 supra, makes this most obvious.

162. The Court in Owen does not stress this point and, indeed, conflates the refusal of this request with the refusal of an earlier request by Owen, made prior to the council's actions. 445 U.S. at 633 n.13. 
duced to a suit for damages in lieu of backpay. ${ }^{163}$ The question before the Supreme Court was whether the city could claim a qualified immunity of the sort available to an executive official in a damage action when he or she is said to have deprived someone of a constitutional right that was not clearly established at the time of the official's actions. ${ }^{164}$ In $O$ wen, the court of appeals had held, a qualified immunity of this sort would relieve the city of liability, for the applicable constitutional rule requiring notice and an opportunity for a hearing ${ }^{165}$ had not been declared by the Supreme Court until ten weeks after the discharge of plaintiff Owen.

As in Monell this question of immunity was regarded as turning on the interpretation of section 1983:166 Had Congress, in enacting that statute, intended to preserve or create a qualified immunity for municipal corporations? The answer was no, the court concluded, because by 1871 , the year of the statute's passage, corporations, including municipalities, "were treated as natural persons for virtually all purposes of constitutional and statutory analysis."167 Justice Brennan found no relevant functional protections of the sort that had been found to immunize individuals sued for misconduct committed while in office. ${ }^{168}$ In this part of the opinion, the Court in Owen, as in Monell, built on a presumed statutory conflation of institutional into individual liability, but here, ironically, the ultimate effect is to expand municipal liability beyond that imposed upon individuals.

But Brennan departed from the Monell analogy between institutional and individual liability in his rejection of the argument that municipal immunity, even if not available at common law in 1871, must have been intended to have been incorporated into section 1983 because it is most compatible with the purposes of the statute. In this discussion, which focused on the consequences of imposing a damage remedy on a city, the Court accepted cost-allocation ${ }^{169}$ and lossspreading arguments that had been implicitly rejected in Monell and other decisions that addressed the scope of municipal liability. Once the local government has been found to be "responsible" under the test imposed by Monell, the Court concluded, it is fair to impose dam-

163. 445 U.S. at 632 n.12.

164. Harlow v. Fitzgerald, 457 U.S. 800 (1982); Wood v. Strickland, 420 U.S. 308 (1975).

165. Board of Regents v. Roth, 408 U.S. 564 (1972).

166. 445 U.S. at 635.

167. 445 U.S. at 639.

168. Justice Powell dissented on this point, powerfully challenging Justice Brennan's conclusion that the nineteenth-century cases refusing to hold municipalities liable for governmental and discretionary activities were not applicable to section 1983 liability. 445 U.S. at 676-79.

169. 445 U.S. at 655. 
ages in order to serve cost-allocation principles of deterrence and loss spreading. ${ }^{170}$ The justifications for such cost allocations are described with explicit reference to the possibility of controlling the more amorphous harms that can be caused by institutional structures. The threat of damage liability, Justice Brennan thought,

may encourage those in a policymaking position to institute internal rules and programs designed to minimize the likelihood of unintentional infringements on constitutional rights. Such procedures are particularly beneficial in preventing those "systemic" injuries that result not so much from the conduct of any single individual, but from the interactive behavior of several government officials, each of whom may be acting in good faith. ${ }^{171}$

Perhaps, the Justice added, the threat of liability would "increase the attentiveness with which officials at the higher levels of government supervise the conduct of their subordinates."172

This seems quite unlike the caution inherent in the rationales of Rizzo and Monell, and indeed, these goals simply cannot be achieved given the Court's exclusion of most, perhaps all, systemic injuries from the sphere of "official policy." Yet the Court in Owen went even further: it concluded that it is fair to hold the government liable in damages simply as a matter of equitable loss spreading. ${ }^{173}$ The constitutional wrong becomes one of those "inevitable costs of government [which should be] borne by all the taxpayers [rather than] . . . those whose rights ... have been violated." 174 It may seem callous to talk about constitutional violations as an inevitable cost of government business. But Justice Brennan was talking about a constitutional development that, by hypothesis, "could not have been foreseen by municipal officials." 175 It is also significant that this was litigation against the government as employer. It is easier to see the employment torts of government as simply the costs of government business. In most employment cases, in contrast to cases of, say, police or prison guard misconduct, the financial interest of the government is obvious and unremarkable, and the government seldom commits harms of that special level of seriousness that cannot be duplicated by private individuals. ${ }^{176}$ The Court was also, it is important to remember, careful to

170. See, e.g., 445 U.S. at 655 n.39.

171. 445 U.S. at 652 (footnotes omitted); see also 445 U.S. at 656 (arguing that the threat of municipal liability provides an incentive for municipal officials to act conscientiously).

172. 445 U.S. at 652 n.36.

173. 445 U.S. at $655,657$.

174. 445 U.S. at 655.

175. 445 U.S. at 655.

176. The Court, in its discussion of the nineteenth-century cases, noted that it was commonplace to sue cities for violations of contract, including contracts for employment under actions of 
stress that rationales of deterrence and loss spreading would be heard only on the question of remedy. Loss spreading may have "joined fault as a factor in distributing the costs of official misconduct," 177 but "the public will be forced to bear only the costs of injury inflicted by 'the execution of a government's policy or custom' " within the terms of Monell. ${ }^{178}$

\section{B. Due Process: Parratt and Logan}

The Court has on other occasions found it easy, even natural, to evaluate the impact of an institutional structure as a whole on an injured individual. I shall describe two recent examples. One of them was overruled when the Court belatedly realized that it was slipping away from the individual wrongdoer model; the other is still sound law. Like Owen, they are both cases claiming a violation of due process: Parratt v. Taylor ${ }^{179}$ and Logan v. Zimmerman Brush Co. ${ }^{180}$

In Parratt and Logan, even more than in Owen, it is not easy to say that there is an identifiable wrongdoer, or even an identifiable decision, and the Court does not point to either. Parratt was brought by a prisoner, Taylor, whose hobby kit, ordered through the mail, was lost at some point between its arrival at the prison and Taylor's release from segregation. Taylor sued the warden and the prison hobby manager, alleging that they had deprived him of his property without due process of law and seeking damages that reflected the (relatively minor) value of the lost kit.

Procedural due process cases like Parratt have frustrated the courts because they look, on their facts, so much like ordinary common-law torts, yet a constitutional claim is clearly being made. It was this sort of case that led some judges to conclude that negligent wrongdoing was not sufficient, absent proof of wrongful intent, to support a constitutional tort action. ${ }^{181}$ In Parratt the Supreme Court realized that requiring a showing of something more than negligence was the wrong answer to the wrong question, that neither section 1983 nor any

wrongful discharge. 445 U.S. at 638-39 \& n.19. Of course, it is critical to the finding that there was a deprivation of liberty in this case that something more than a contract was at stake. The wrongful discharge becomes of constitutional importance only because it is associated with an injury to the employee's reputation. See text at note 155 supra. But see Cleveland Bd. of Educ. v. Loudermill, 470 U.S. 532 (1985) (holding that in some instances an individual may have a constitutionally protected property interest in continued public employment).

177. 445 U.S. at 657.

178. 445 U.S. at 657.

179. 451 U.S. 527 (1981).

180. 455 U.S. 422 (1982).

181. See text at note 19 supra. 
general principle of constitutional law made degree of culpability relevant. ${ }^{182}$ The question whether something more than negligence might be required only seemed relevant because of the false analogy to common-law tort with its inquiry into individualized wrongdoing. To focus on the distinction between intentional and negligent ${ }^{183}$ acts was to lift common-law language inappropriately into a constitutional case.

Taylor could prove nothing more than negligence on the part of prison officials. Yet his claim that he had been deprived of his property without constitutionally required process was not implausible, for he had lost his property at the hands of people empowered by the state, and neither a prior hearing nor prior notice had been provided. ${ }^{184}$ The Court found, however, that Taylor had failed to state a constitutional claim - not because he could only allege negligence, but because postdeprivation remedies available through the state could provide due process. Obviously, this holding gave the prisoner less than he might have hoped; he had been seeking a postdeprivation remedy in the federal court. Yet the Court in Parratt still had done something remarkable. Its reasoning broke away from the common-law model - which defines the wrongdoer and the wronged narrowly and evaluated whether a constitutional wrong had occurred by looking at the operation of the system as a whole. One branch of the state deprived Taylor of his hobby kit; another could provide the necessary hearing and, if appropriate, compensation.

Taylor might have expected a federal damage remedy because he was looking at his injury through the common-law model: he had been deprived of his property by the prison employees who lost the hobby kit, and he thought that he should have an action against them.

182. 451 U.S. at 554-55 (Marshall, J., concurring in part and dissenting in part).

183. Note that negligent acts might be either inadvertent or deliberate. See Davidson v. Cannon, 106 S. Ct. 668, 673 n.2 (1986) (Blackmun, J., dissenting). White v. Rochford, 592 F.2d 381 (7th Cir. 1979), cited by Justice Blackmun, $106 \mathrm{~S}$. Ct. at 674 n.3, illustrates this point: The allegations in that case were that police officers, upon arresting the driver of a car, refused to provide assistance to three minor children, including a five-year-old asthmatic, accompanying him. The children were left in the abandoned car at night on a busy limited-access highway. Although the case involved police decisions and action that was not inadvertent, it would most likely be analyzed at common law in terms of negligence rather than intentional tort. The common-law distinction between intent and negligence hinges on the existence of a quite specific kind of intent - for example, in battery, the intent to have a harmful or offensive contact with another person. (Here a case might be made out in false imprisonment, which requires proof of intent to confine or, perhaps, to commit some other trespass to the person.) Where no such intent has been established, no intentional tort can be made out even if a decision (for example, a decision to leave a car parked on a very steep slope) has been made. But the case can still be analyzed in terms of negligence - or, perhaps, strict liability.

184. Taylor could point to no decision to take his property. 451 U.S. at 543 . If there had been such a decision, even with notice and opportunity for a hearing, the taking would have been intentional. 
Section 1983, if it were read to authorize an award of damages equivalent to the lost kit, could provide that action. Under that approach, however, the overlap between constitutional and common law would be too great. The Court adopted a broader perspective. It defined a wrong without a specifiable wrongdoer: any constitutional injury that might exist would be that inflicted by the state system as a whole where it failed to provide due process, and not by the individual employees who had allegedly lost the hobby kit. ${ }^{185}$ Under the circumstances, this analysis made considerable sense, for where the loss is not deliberate the actors responsible for the deprivation have made no decision of the sort that a prior hearing could inform. But the fact that a loss is not deliberate does not mean that no predeprivation steps are available to government actors. Where the risk of loss is foreseeable and sufficiently high, due process may be said to require that steps be taken to minimize that risk. ${ }^{186}$ Though the loss of the property in a situation like Parratt ${ }^{187}$ is not intended, the failure to provide these safeguards might itself be either deliberate or inadvertent, depending on whether the risk had been explicitly focused upon in the design of the institutional structure. The Court in Parratt did not address that question, perhaps because it assumed that "process" referred to the sort of safeguards, such as hearings, that might surround individuated

185. The separate opinions of Justice Blackmun, concurring, and Justice Marshall, concurring in part and dissenting in part, suggest alternative approaches that would also require the Court to consider the institutional procedures as a whole, rather than simply the act that caused the loss. Justice Blackmun asserted: "When it is possible for a State to institute procedures to contain and direct the intentional actions of its officials, it should be required, as a matter of due process, to do so." 451 U.S. at 546. Justice Marshall was concerned that the state had not alleged that it had informed Taylor of his right to sue under state tort law: "In cases such as this, I believe prison officials have an affirmative obligation to inform a prisoner who claims that he is aggrieved by official action about the remedies available under state law." 451 U.S. at 556.

186. See Parratt, 451 U.S. at 546 (Blackmun, J., concurring); Davidson v. Cannon, 106 S. Ct. 668,673 n.2 (1986) (Blackmun, J., dissenting) ("In some circumstances, the risk of injury is so high that the government's failure to make efforts to avoid the injury is unacceptable, even if its omission still might be categorized as negligence."); see also Baker v. McCollan, 443 U.S. 137, 153-54 (1979) (Stevens, J., dissenting) ("[P]olice officers must conform to procedures mandated by the Constitution which serve to minimize the risk of wrongful and unjustified deprivations of personal liberty.").

187. Three years after Parratt, the Court decided Hudson v. Palmer, 468 U.S. 517 (1984), in which it applied the Parratt analysis to a case in which the plaintiff had alleged that a prison guard had intentionally deprived him of noncontraband personal property. The Court described the reasoning of Parratt as follows: "that where a loss of property is occasioned by a random, unauthorized act by a state employee, rather than by an established state procedure, the state cannot predict when the loss will occur ... [and] predeprivation procedures are simply "impracticable." " 468 U.S. at 532-33. This reading of Parratt, in a suit brought only against the prison guard who was alleged to have taken the property, is oddly reminiscent of the "official policy and custom" cases, which also emphasize the existence of authority for official conduct. The question becomes: What could the state have done differently? And the answer given is: "Nothing, when the action of the guard was unauthorized." No inquiry is made into whether the state encouraged, tolerated, or facilitated the intentional conduct of its employee. 
decisions made in particular cases. It thought, therefore, only of what could be done for Taylor, and after-the-fact compensation seemed enough.

The Court did not say who could be sued if there were no postdeprivation procedures and their absence was found to violate the constitutional guarantees of due process. There was a suggestion that it might then be appropriate to sue the prison employees for the price of the lost property. ${ }^{188}$ That is, one way to redress a lack in the state remedial structure would be to provide an alternative damage remedy in federal court. This approach would not only raise the problem of overlap with tort described above, but would also provide, at best, a partial, temporary, solution. The prison employees who lost the kit were not in a position to remedy the constitutional lack of due process. They were unlikely to have either the power to create a postdeprivation remedy or the power to bring about changes in institutional processes that would minimize the risk of loss. Again, no single person or body in a Parratt situation is responsible for the harm. The injury is caused by the way in which the different parts of the system fit together. One arm of the state brings about the deprivation and another fails to provide the process required by law. An alternative remedy, one that would be more consistent with the theory of the case, would be to grant declaratory or injunctive relief against the state prison offcials, requiring that adequate process be provided. This would avoid the unfairness of holding individual officials liable in federal court for a wrong attributable to the structure of the system. ${ }^{189}$ It would also respond to Justice Powell's concern, in his concurrence, that the real wrongdoers under the Parratt theory are the state or its lawmakers, both of whom are immune from damage liability. 190

Logan v. Zimmerman Brush Co. ${ }^{191}$ is also a due process case,

188. The ground for reversal in Parratt itself was that due process is sufficiently provided where " $[t]$ here is no contention that the procedures themselves are inadequate," 451 U.S. at 543 , leaving the negative implication that a different result would be appropriate where such a contention is made. A suit for damages against the state itself would be barred by the eleventh amendment, Edelman v. Jordan, 415 U.S. 651 (1974), and damage actions against the legislators and judges who design and articulate state compensatory remedies would be barred by doctrines of official immunity. Supreme Court of Va. v. Consumers Union, 446 U.S. 719, 732-35 (1980); Pierson v. Ray, 386 U.S. 547 (1967).

189. See Whitman, supra note 121 , at $57,60-62$.

190. 451 U.S. at 550 n.8. The plaintiff could proceed against state officials for injunctive relief under Ex Parte Young, 209 U.S. 123 (1908), but would be barred by the eleventh amendment from recovering retrospective relief such as damages. Edelman v. Jordan, 415 U.S. 651 (1974). The eleventh amendment does not provide similar protection for local governments, although, of course, the plaintiff in suits against these entities must establish "official policy or custom." Monell, 436 U.S. at 694.

191. 455 U.S. 422 (1982). 
though it stands on the border between procedure and substance. It was not an action brought under section 1983, but an appeal from a state supreme court decision in favor of a private employer in a case brought under the Illinois Fair Employment Practices Act. Appellant Logan had filed a charge of discrimination with the Illinois Fair Employment Practices Commission. Although the state statute required the commission to convene a factfinding conference within 120 days of the bringing of the charge, the conference on Logan's complaint was scheduled by the commission for five days after the expiration of the statutory period. The untimely scheduling of the conference was apparently inadvertent and, of course, completely beyond Logan's control. However, at the employer's petition the state supreme court held that this failure to comply with the statutory time limit deprived the commission of jurisdiction and extinguished Logan's claim.

The United States Supreme Court reversed, concluding that a state "may not finally destroy a property interest [here, Logan's right to use the commission procedures] without first giving the putative owner an opportunity to present his claim of entitlement."192 Again, it was only because of the combined effect of actions by several different arms of the state that a constitutional wrong had been done. The Court did not say that the commission had acted unconstitutionally in scheduling the factfinding conference beyond the 120-day period; in fact, the commission had denied the employer's request to dismiss Logan's complaint. What was unconstitutional was to give the commission's error the significance it was given by the Illinois Supreme Court, to make it the grounds for destroying Logan's claim. The United States Supreme Court found constitutional error by looking at the way in which the claim-processing system worked as a whole. It asked whether the state structure was consistent with constitutional requirements of fair procedure. The case stands at the border between substantive and procedural due process ${ }^{193}$ because the Court did not ask whether the decision to deprive Logan of his claim - a decision that can be said to have been made either by the state legislature in imposing the 120-day limit or by the state supreme court in enforcing that limit in this way - was made with fair procedures, but whether that decision could be reached at all.

In both Parratt and Logan the Court was properly sensitive to the

192. 455 U.S. at 434.

193. The majority, however, characterized the case only as one involving procedural due process. 455 U.S. at 433-38. A separate opinion written by Justice Blackmun, the author of the majority opinion, and joined by three other Justices, also found the Illinois scheme to violate Logan's right to equal protection. 455 U.S. at 438-42. Justice Powell, joined by Justice Rehnquist, concurred in the judgment solely on equal protection grounds. 455 U.S. at 443-44. 
design of a state system in its handling of citizen concerns, and to the possibility that structural design may create constitutional questions through either deliberate omissions or inadvertence. (It is possible, even probable, that the Illinois legislature in prescribing the 120-day limit never asked what sanctions would be imposed if the commission failed to act within that time period.) What the Court seemed to require of the system was not anything remarkable, but simply that fair weight be given to the interests of those whom the institution affects. This is a requirement that is reminiscent of the commands of commonlaw torts. But it takes special form when there is no single act or single actor. And, of course, when government conduct is at stake, the standards to be met are found in the particular requirements of the Constitution. When the defendant is no longer an individual like the plaintiff, nor private and thus presumably motivated by self-interest, greater claims may appropriately be made.

Although Logan and Parratt addressed the constitutional question whether due process had been complied with, rather than the statutory issue raised by suits against government defendants, the language used to attribute responsibility to government has influenced the discussion of these constitutional matters too. Both Logan and Parratt appropriately looked to the impact of the government's actions as a whole on the federal plaintiff, rather than engaging in a search for an individual or individuals whose culpability could be measured by standards familiar from tort. But the Court has not been able to maintain this direction without hesitation. When it found that applying Parratt would require it to address new questions in new ways, it retreated abruptly to the more familiar emphasis on state-of-mind and negligence-versus-intent borrowed from tort. The retreat came last Term in two prison cases, Daniels v. Williams ${ }^{194}$ and Davidson v. Cannon. ${ }^{195}$

Neither action was a suit against a government entity defendant. Daniels, who had been a prisoner in a Richmond, Virginia, jail, sued a deputy who had negligently left newspapers and a pillow on a prison stairway. Daniels slipped on these materials, fell, suffered back and ankle injuries, and alleged in his section 1983 action that the state remedy for his injuries was inadequate. ${ }^{196}$ Davidson, while incarcerated in a New Jersey state prison, was attacked by another prisoner, who

194. 106 S. Ct. 662 (1986).

195. 106 S. Ct. 668 (1986).

196. The Virginia Tort Claims Act applied only to actions accruing on or after July 1, 1982; Daniels was injured before that date. The Fourth Circuit, in affirming the dismissal of Daniels' claim by the federal district court, apparently concluded that the deputy's sovereign immunity defense would fail under state law. Daniels v. Williams, 748 F.2d 229, 232 \& n.5 (4th Cir. 1984). 
stabbed him with a fork about his face and body. Davidson's section 1983 action was brought against prison officials who had failed to respond to a note in which he reported a threat that preceded the attack and, at least implicitly, requested protection. New Jersey, by statute, provided that: "Neither a public entity nor a public employee is liable for . . . any injury caused by . . . a prisoner to any other prisoner."197 Both plaintiffs argued that the inadequacy of the state postdeprivation remedies violated due process under Parratt. The Supreme Court, in opinions by Justice Rehnquist, held that neither plaintiff had made out a constitutional case.

As in earlier opinions, Justice Rehnquist described the problem before the Court as "determining when tortious conduct by state officials rises to the level of a constitutional tort." 198 He held that Parratt was in error insofar as it had concluded that an unintended loss caused by the negligent conduct of government officials could be a "deprivation" implicating the due process clause. If the plaintiff could prove no intent to deprive him of his property or to injure him physically, there was no "deprivation" of an interest and therefore no need to reach the question of what process was due. Once more, individual culpability - the ascertainment of a particular state of mind held by a government official or officials - was made an essential inquiry in establishing a constitutional claim. Justice Rehnquist's reasoning in Daniels ${ }^{199}$ was sparse at best. It consisted primarily of the announcement that the Court had been persuaded to adopt a concurrence written by Justice Powell in Parratt, along with brief quotations from that opinion and from Justice Stewart's concurrence in the same case. This is the heart of the Daniels opinion:

Not only does the word "deprive" in the Due Process Clause connote more than a negligent act, but we should not "open the federal courts to lawsuits where there has been no affirmative abuse of power." [Parratt, 451 U.S.] at 548-549 [Powell, J., concurring in the result]; see also id., at 545 ... (Stewart J., concurring) ("To hold that this kind of loss is a deprivation of property within the meaning of the Fourteenth Amendment seems not only to trivialize, but grossly to distort the meaning and intent of the Constitution"). Upon reflection, we agree and overrule Parratt ....200

The key to what rises to the level of a constitutional violation was described, appropriately enough, as the "affirmative abuse of power." The assumption in Daniels, however, was that power can be abused

197. N.J. STAT. ANN. § 59:5-2(b)(4) (West 1982).

198. $106 \mathrm{~S}$. Ct. at 664.

199. Davidson simply applied the Daniels rule in an even briefer opinion.

200. $106 \mathrm{~S}$. Ct. at $664-65$. 
only through those particular acts that would also meet the requirements of the more egregious common-law torts. The claims made in Daniels and Davidson, Justice Rehnquist thought, would require that the Constitution "supplant traditional tort law in laying down rules of conduct to regulate liability for injuries that attend living together in society."201 The post-Parratt cases involving intentional acts by government officials ${ }^{202}$ were described as involving "quite different" claims. ${ }^{203}$ The distinction seems to be between negligence and intentional torts. 204

But neither Daniels nor Davidson had suffered ordinary injuries of the sort that private individuals inflict upon each other in the course of living together. As Justice Blackmun pointed out in his dissent, Davidson had been "stripped [by the state] of all means of self protection"20s and forced to live among very dangerous people. And, as Parratt accurately recognized, both Davidson and Daniels, unlike individuals injured by other individuals, had been deprived by the state of a remedy for compensation. Daniels' fall could have happened on any stairway - a point that eight Justices stress - but this stairway, unlike most others, was owned by an entity that could give itself special protection against suit. To provide that special protection may not be an abuse of power, ${ }^{206}$ but it is certainly an exercise of power that raises questions not reached by common-law tort.

The holding of Daniels and Davidson applies to all claims brought under the due process clause, for the requirements of that constitutional provision, be they substantive or procedural, apply only when the plaintiff has suffered a "deprivation."207 But the Court's emphasis on deliberateness and intent makes most sense as a narrow reading of those situations in which procedural safeguards are due. Read this

201. $106 \mathrm{~S}$. Ct. at 666 . Rehnquist continued by quoting the concern he expressed in Paul v. Davis, 424 U.S. 693, 701 (1976), that the fourteenth amendment not be made "a font of tort law to be superimposed upon whatever systems may already be administered by the States."

202. E.g., Hudson v. Palmer, 468 U.S. 517 (1984); Curtis v. Everette, 489 F.2d 516 (3d Cir. 1973), cert. denied, 416 U.S. 995 (1974); Johnson v. Glick, 481 F.2d 1028 (2d Cir.), cert. denied, 414 U.S. 1033 (1973).

203. Davidson, $106 \mathrm{~S}$. Ct. at 670.

204. Justice Brennan, who joined the majority in Daniels, Justice Marshall, who concurred in the result, and Justice Blackmun, who concurred in the judgment, all dissented in Davidson on the ground that the officials' conduct in that case was sufficiently serious to be described as exhibiting recklessness or deliberate indifference, rather than being "merely negligent." $106 \mathrm{~S}$. Ct. at 671,675 .

205. $106 \mathrm{~S}$. Ct. at 671 .

206. See Justice Stevens' opinion concurring in the judgments, $106 \mathrm{~S}$. Ct. at 677 (discussed in text at note 217 infra).

207. Justice Rehnquist cited substantive due process cases, such as Rochin v. California, 342 U.S. 165 (1952), as well as procedural due process cases, as support for his narrow definition of "deprivation." See 106 S. Ct. at 665. 
way, Daniels and Davidson could be said implicitly to define procedural due process protections as necessary only when government "agents decide to 'deprive any person of life, liberty, or property," "208 on the basis of facts that might be misperceived. If the only constitutionally required procedures are those designed to minimize factual error in government decisionmaking, it is plausible to insist on some showing that a decision has been made. The required procedures need not be adversarial. (They could, as was argued in Baker v. McCollan, ${ }^{209}$ consist of checking files to ascertain the true identity of a prisoner who protests that he is not the man wanted by the police.) And they could, perhaps, be provided after the fact. ${ }^{210}$ If a decision has been made and proper procedures have been followed, there should be no liability for error. ${ }^{211}$

But Daniels and Davidson were not written as procedural due process cases. And, if the question of constitutional interpretation turns on the word "deprivation," rather than on what process is due, the quality of the loss to the plaintiff is at least as important as the wrongfulness of any official's conduct. ${ }^{212}$ If the cases were intended to address questions beyond the procedural safeguards necessary in the making of fact-based decisions, and the effect of government action on the plaintiff is to be weighed, it is not so easy to see why questions of abuse of power are not raised when the government fails to take steps to minimize inadvertent loss or provides itself with a unique immunity from suits for compensation. Government practices and institutional structures can create special and impermissible harms whether they are the result of deliberate decisions or inadvertence.

208. Daniels, 106 S. Ct. at 665.

209. 443 U.S. 137, 143 (1979).

210. The survival of Hudson v. Palmer, 468 U.S. 517 (1984), which applied Parratt in finding postdeprivation state remedies sufficient to satisfy due process when a prison guard is alleged to have stolen a prisoner's property, could be justified on this ground. The state might fairly be asked to take steps to minimize official wrongdoing of this sort and to provide compensation after the loss, but, if all that is necessary in that regard has been done, it is absurd to argue that prior procedures be followed to ensure the correctness of a decision (the guard's decision to steal) that all, including the decisionmaker, would concede is inappropriate or even illegal.

211. For example, in Davidson, as Justice Blackmun pointed out, government officials made at least two decisions. Two of the defendants, the assistant superintendent of the prison and a corrections sergeant, decided, at separate times, not to take prompt action on being notified of the threat. $106 \mathrm{~S}$. Ct. at 672,675 . These decisions may have been unreasonable, and thus negligent, but they were made intentionally. (Unintentional negligence came into play later, when the sergeant left the prison having forgotten Davidson's note. $106 \mathrm{~S}$. Ct. at 672.) Yet, these are not the sort of government decisions that would normally require a prior hearing. Nor was any allegation made that a change in institutional processes would have reduced the risk of error. An error in result does not in itself indicate abuse of government power.

212. As Justice Stevens said, in his opinion concurring in the judgments, " 'Deprivation,' it seems to me, identifies, not the actor's state of mind, but the victim's infringement or loss." 106 S. Ct. at 680 . 
The Court dismissed the claims brought in Daniels and Davidson because the front-line officials - the deputy who left the pillow on the stairs and the correctional officials who failed to respond to Davidson's request for protection - had made no deliberate decision to injure the plaintiffs. But deliberate decisions were in fact at issue in both cases, for the basic challenge of each plaintiff was to the state's refusal to provide compensatory relief. A state's decision to invoke sovereign immunity ${ }^{213}$ raises a question that, even under the Court's analysis, should be asked: Is the decision to deny a remedy under the circumstances an "arbitrary exercise of the powers of government"214 or governmental power "used for purposes of oppression"?215 Justice Rehnquist overlooked these decisions - including the embodiment of New Jersey's choice in that most "official" of forms, a statute - because he saw these as tort cases between the individuals who had suffered loss and the government agents who had dealt with them directly. 216

To ask whether the invocation of sovereign immunity is an abuse of governmental power is not to answer that question in the affirmative. It is far from unreasonable, for instance, for government to provide protection for its agents, coupled with mechanisms for internal discipline and the possibility of compensation from public resources. Even a flat protection in certain cases, such as prisoner suits, may be found to be not unfair. Indeed, that was Justice Stevens' conclusion in Davidson, where he asked the question posed above and concluded that there was no violation of the Constitution. ${ }^{217}$

If the Court could have preserved the analysis of Parratt and still

213. In Daniels, immunity was raised by the defendant, though the court of appeals thought that it would not in fact be available under Virginia law. 748 F.2d at $232 \&$ n.5. There was a clear legislative decision to make the Tort Claims Act, VA. CODE ANN. § 8.01-195.1 (1984), apply only to claims accruing on or after July 1982. In Davidson, a legislative decision to provide immunity to both the state and its officials was embodied in the statute. $106 \mathrm{~S}$. Ct. at 670 (quoting N.J. STat. ANN. $§ 59: 5-2(b)(4)$ (West 1982)).

214. 106 S. Ct. at 665 (quoting Hurtado v. California, 110 U.S. 516, 527 (1884)).

215. 106 S. Ct. at 665 (quoting Murray's Lessee v. Hoboken Land \& Improvement Co., 59 U.S. (18 How.) 272, 277 (1850)).

216. See Justice Rehnquist's description of Daniels and Parratt as involving "the actions of prison custodians in leaving a pillow on the prison stairs, [and] mislaying an inmate's property," Daniels, $106 \mathrm{~S}$. Ct. at 665, as well as his distinction of Wolff v. McDonnell, 418 U.S. 539 (1974), as implicating due process because it involved a "deliberate decision to deprive [a specific] inmate of good-time credit." $106 \mathrm{~S}$. Ct. at 666.

Justice Rehnquist could have been encouraged to characterize these cases in this way by the fact that these front-line officials were the defendants named by the plaintiffs. But that litigation choice was the one to which plaintiffs were, perhaps erroneously, directed by Parratt. See text at notes 188-90 supra.

217. $106 \mathrm{~S}$. Ct. at 681 . Justice Stevens' concurrence in Daniels is based upon his deference to the Fourth Circuit's conclusion that Virginia law would not have defeated the prisoner's claim. 10 ó S. Ct. at 680 . 
defeated plaintiff's claim, why did it so forcefully back away from that case? The Justices may have feared that they were about to venture into an area where the temptation to ask too much of government would be very strong. ${ }^{218}$ But that temptation could have been addressed directly, as it was in Justice Stevens' concurrence. Instead, the Court's shift in direction seems to reflect the view, expressed most forcefully in Rizzo v. Goode, ${ }^{219}$ that constitutional litigation is not appropriately used to address questions of institutional structures and practices. In this view, constitutional litigation, by analogy to tort, redresses only those injuries caused by aberrant individual defendants who have violated social norms for personal behavior. Yet, from Paul v. Davis, 220 in which Justice Rehnquist first expressed his concern that constitutional litigation not be "a font of tort law," through Daniels and Davidson, which are the most recent expression of that preoccupation, the Court has also sought to distinguish constitutional cases from tort. It has sought to do so by defining constitutional cases as falling into some particularly egregious subcategory of torts, rather than by taking the opportunity to develop a vocabulary, truly independent from tort, that could be used to discuss the special problems created by the massing of power in institutions. In due process cases, as in litigation involving municipal liability, the Court has assumed that those cases sufficiently serious to merit constitutional attention are the cases that parallel "the most serious"221 torts, where the plaintiff can point to a deliberate decision to act wrongfully. Yet, by the Court's own description, the special character of the Constitution is that it directly addresses questions of structure and the abuse of power.

Focusing on structures and processes as mechanisms for the abuse of power may indeed lead the courts to questions that they have not faced before. Many of these questions will be difficult. But it will be even more difficult to maintain the fiction that all questions of responsibility for harm can be answered by reference to norms developed for individual behavior. The effort to maintain that fiction leads only to such futile doctrinal developments as the attempt to find a governmen-

218. See text at notes $144-48$ supra.

219. 423 U.S. 362 , 371 (1976).

220. 424 U.S. 693, 701 (1976).

221. Intentional torts might seem most serious because some of the conduct that they reach may also be subject to criminal sanctions, and some torts, such as trespass, share the origins of similarly named criminal actions. Also, punitive damages, which are unavailable for simple negligence, see, e.g., Spackman v. Ralph M. Parsons Co., 147 Mont. 500, 414 P.2d 918 (1966), may be available for intentional torts accompanied by circumstances of aggravation or outrage. Birmingham Waterworks Co. v. Brooks, 16 Ala. App. 209, 76 So. 515 (1916); Chiles v. Drake, 59 Ky. (2 Metc.) 146 (1859). But see text at notes 115-18 supra (state of mind required to establish intentional tort is not necessarily indicative of evil motive). 
tal "mind" or the refusal to recognize that a loss can be felt as keenly when it comes about through the negligent misuse of state power as when it comes about through intentional abuse. Legitimacy depends at least as much upon credibility as upon caution in asking new questions.

If a vocabulary for resolving questions of institutional responsibility were developed in constitutional litigation, it might, of course, prove useful in tort. Once we see how injuries can be caused by institutions in ways not analogous to harm caused by individuals, claims similar to those brought in litigation against the government might be raised against other powerful institutions. For example: The "due process" demand for access, for consideration, might as easily be made upon private but powerful institutions, and it could be vindicated, where appropriate, as a common-law tort. Or tort might address institutional practices that intensify the impact of racist or sexist biases. Tort law might focus more deliberately, not on actual or hypothetical individual behavior, but on whether practices or structures have contributed significantly to the creation of undesirable consequences.

A shift of focus beyond questions of individual wrongdoing is important. Our struggle with the consequences of racism and sexism has made us aware that injuries do not flow solely from the acts of evil or careless persons. And we have begun to be open to the possibility that characteristics attributed to women or minorities, as a class or as individuals, may be the consequence of social structures and expectations. Neither torts nor constitutional law can ensure individual fulfillment. Relief from abuse of power is important in furthering individual liberty, but so is a sense of responsibility for one's own life and the existence of groups that can be a source of strength and fellowship. The law cannot give us all jobs in a depressed economy. It does not help us to resist the temptations of flattery. It offers no relief from the casual cruelties of friends and strangers. But a law that addresses only the isolated behavior of individuals, whether private or official, sees only some of the ways in which power can be abused, and the abuse of power is a subject with which the law is properly concerned. 